\title{
La suspensión cautelar en los procesos de selección de funcionarios públicos
}

\author{
Juan José Fernán dez Domínguez \\ Catedrático de Derecho del Trabajo \\ y de la Seguridad Social \\ Susana Rodríguez Escanciano \\ Profesora Titular de Derecho del Trabajo \\ y de la Seguridad Social. \\ Universidad de León
}

\begin{abstract}
SUMARIO : 1.- PLANTEAMIENTO. 2.- LA SUSPENSIÓN JUDICIAL DE ACTOS ADMINISTRATIVOS COMO MEDIDA DE TUTELA "PROVISIONALÍSIMA". 3.- REQUISITOS. 3.1.- Breve referencia al ordenamiento comunitario. 3.2.- Su plasmación en el Derecho interno. 3.2.1.- La prueba sobre la necesidad de paralización. 3.2.2.- Imposibilidad de prejuzgar el fondo del asunto. 3.2.3.- El periculum in mora. 3.2.4.- La ponderación de los intereses concurrentes. 3.2.5.- El fumus boni iuris. 4.- LA APLICACIÓN DE LOS REQUISITOS EXIGIDOS PARA LA SUSPENSIÓN CAUTELAR EN LOS PROCESOS DE SELECCIÓN DE LOS FUNCIONARIOS. 4.1.- El debido respeto a los principios de mérito capacidad. 4.2.- Detalle de supuestos concretos. 4.3.- Revisión de los actos de reclutamiento y discrecionalidad técnica. 5.- REFLEXIONES FINALES.
\end{abstract}

\section{PLANTEAMIENTO}

La tensión entre la ejecutoriedad de los actos administrativos, pese a su impugnación jurisdiccional, y las consecuencias que de aquélla se pueden derivar en perjuicio del recurrente, ha sido tradicionalmente resuelta atendiendo prioritariamente a las exigencias de funcionamiento de la Administración ${ }^{1}$.

\footnotetext{
${ }^{1}$ GARCÍA DE ENTERRIA, E.: La batalla por las medidas cautelares, Madrid, 2ª edición, 1995, pág. 13.
} 
La necesidad de servir con eficacia a los intereses generales justifica, en principio, que los actos administrativos sean inmediatamente ejecutivos, y que la interposición del recurso no sea suficiente para paralizar dicha efectividad. Ahora bien, no cabe desconocer tampoco cómo el inicio de un proceso judicial obedece al deseo de una de las partes de obtener del juez un pronunciamiento favorable capaz de agotar por sí solo los móviles que alentaron el comienzo del pleito. La satisfacción de las pretensiones es, pues, la razón primera yúltima del juicio, motivo por el cual deviene preciso dotarla de los mecanismos necesarios para que, una vez dictada la sentencia, si ésta considera legítimo lo solicitado, encuentre plena satisfacción la pretensión postulada. La función jurisdiccional necesita, por tanto, de unos instrumentos destinados a evitar el hecho de que circunstancias acaecidas en el curso de la tramitación procesal pongan en peligro los resultados derivados del contenido del fallo judicial².

A obviar tales peligros atienden precisamente las medidas cautelares, presentes en las distintas jurisdicciones, y también -cómo no- en el marco del proceso contencioso-administrativo ${ }^{3}$, donde la instauración de una tutela judicial efectiva ha llevado a revisar todas las fórmulas de defensa de los particulares frente a la Administración, siendo la suspensión de los actos una de las más importantes ${ }^{4}$. No es que la ejecutividad y la ejecutoriedad de la actuación administrativa hayan desaparecido por mor de la relevancia del derecho fundamental a la tutela judicial efectiva, sino que la posibilidad del control judicial de dicho quehacer hace aconsejable (en algunos casos) mantener la situación existente en el momento en el cual se solicita la medida5.

Bajo tales premisas, entrar a valorar si, de conformidad con el ordenamiento jurídico, había que proceder o no a una hipotética suspensión judicial de un acto impugnado cuando de procesos de selección de personal público

2 QUINTANA LÓPEZ, T.: "Las medidas cautelares en el proceso administrativo italiano", Re vista Española de Derecho Administrativo, núm. 64, 1989, pág. 537.

${ }^{3}$ GARCÍA DE ENTERRÍA, E.: "Reflexión sobre la constitucionalización de las medidas cautelares en el contencioso-administrativo", Revista Española de Derecho Administrativo, núm. 76, 1992, págs. 615 y ss.

${ }^{4}$ RODRÍGUEZ-ARANA MUÑOZ, J.F.: "De nuevo sobre la suspensión judicial del acto administrativo (1986-87)", Revista Española de Derecho Administrativo, núm. 64, 1989, págs. 639 y ss.

5 RODRÍGUEZ-ARANA MUÑOZ, J.F.: "Las medidas cautelares en la jurisdicción contencioso-administrativa en España", Revista Aragonesa de Administración Pública, núm. 28, 2006, pág. 139. 
se trata, exige, como paso previo, profundizar en la naturaleza de las medidas cautelares y, en particular, de la "pieza de suspensión"; los requisitos al efecto demandados por la normativa de la U nión Europea y, en especial, por la española; por último, abundar en las singularidades que su aplicación presenta en los procesos de reclutamiento de funcionarios públicos, dado el necesario "casuismo" ( o "forma circunstanciada") al cual Ilaman de continuo los Tribunales.

\section{LA SUSPENSIÓN JUDICIAL DE ACTOS ADMINIST RATIVOS COMO MEDIDA DE TUTELA "PRO VISIONALÍSIMA"}

Dotar de continuidad, regularidad y eficacia al quehacer de las Administraciones ha llevado a reconocer, en la mayor parte de los sistemas jurídicos europeo-occidentales (entre otros el español), el denominado "privilegio de la autotutela", en virtud del cual se impone que "sus actos nazcan con vocación de inmediato cumplimiento, motivo por el cual producen efectos desde la fecha en que se dictan (art. 57 Ley 30/ 1992, de 26 de noviembre, de Régimen Jurídico de las Administraciones Públicas y del Procedimiento Administrativo Común -LRJAP-), son inmediatamente ejecutivos (art. 97 LRJAP) y su impugnación en vía administrativa o judicial no produce la suspensión automática de su ejecución, excepto en los supuestos en que una disposición establezca lo contrario (art. 111 LRJAP) "6. Este criterio sostenido por el legislador ha sido expresamente calificado como "no contrario a la Constitución, sino que [, antes bien,] engarza con el principio de eficacia enunciado en el art. 103.1 CE... [; razón en virtud de la cual] la ejecutividad de sus actos, en términos generales y abstractos, tampoco puede estimarse incompatible con el art. 24.1 CE"7.

El punto de partida queda situado, por tanto, en la apariencia de legalidad de todo acto administrativo, articulado bajo la forma de reconocimiento en su favor de una especie de presunción iuris tantum de legalidad que determina su ejecutividad y ulterior ejecutoriedad a falta de dispensa por resolución judicial ${ }^{8}$.

${ }^{6}$ SAN 11 julio 2007 (JUR 236857).

${ }^{7}$ Entre muchas, SSTCo 66/ 1984, de 6 de junio, 78/ 1996, de 20 de mayo, o los muy ilustrativos AATCo 458, 930 y 1095/ 1988, de 18 de abril, 20 de julio y 6 de octubre.

${ }^{8}$ BOQUERA OLIVER, J.M.: "Insusceptibilidad de la suspensión de la eficacia del acto administrativo", Revista de Administración Pública, núm. 135, 1994, págs. 37 y ss. 
No ha de extrañar, en consecuencia, que la suspensión prevista en el art. 130.1 de la Ley 29/ 1998, de 13 de julio, reguladora de la jurisdicción contencioso-administrativa ( LJCA), haya sido calificada como "una medida provisional de carácter excepcional y de aplicación restrictiva" ${ }^{\prime \prime}$, e incluso que después de la entrada en vigor de la meritada Ley algunos Tribunales Superiores de Justicia sigan entendiendo que "la expresión 'únicamente' [ incorporada en aquel precepto] puede entenderse en el sentido del carácter excepcional de las medidas cautelares frente a la regla general del privilegio de la ejecutividad del acto administrativo y del carácter no suspensivo del recurso"10. Es más, en el sentir de al gunos autores, "el 'únicamente cuando...' del art. 130.1 no se refiere a la anormalidad o frecuencia con que pueden adoptarse las medidas cautelares, sino a su naturaleza de excepción y límite al mentado principio de ejecutividad del acto administrativo"11.

Dista, empero, de ser así, pues según ha corregido en reiterada jurisprudencia el Tribunal Supremo (siguiendo pautas previas sentadas por el Tribunal Constitucional), "la adopción de medidas que permitan asegurar el resultado del proceso no debe contemplarse como una excepción, sino como una facultad que el órgano judicial puede ejecutar siempre que sea necesario"12. De este modo, de una actitud "restrictiva" en materia cautelar se ha pasado a una actitud en cierta medida "favorable" a la misma, en el sentido de poderse considerar matizada la regla de la necesaria prevalencia del interés público ${ }^{13}$.

Este último reconocimiento no debe, con toda su trascendencia, llamar tampoco a engaño alguno, pues no supone una equiparación entre ejecutivi-

${ }^{9}$ ATCo 285/ 1997, de 21 de julio.

10 SSTS) Comunidad Valenciana 20 mayo 2003 (JUR 23534/ 2004) y 17 octubre 2005 (JUR 107758/2006).

${ }^{11}$ CHINCHILLA MARÍN, C.: "Los criterios de adopción de las medidas cautelares en la nueva Ley reguladora de la jurisdicción contencioso-administrativa", en AA.VV (CAMPOS SÁNCHEZ-BORDONA, M., Dir.) : M edidas cautelares en la jurisdicción contencioso-administrativa, Madrid, 1999, pág. 49.

12 Sirvan los ejemplos de un tenor tan repetido que proporcionan los AATS 12 septiembre 2000 (RJ 282/ 2001) y 6 marzo 2001 (RJ 2847).

13 GONZÁLEZ-VARAS IBÁÑEZ, S.: Comentarios a la Ley de la Jurisdicción Contencioso-Administrativa, Madrid, 1999, pág. 560. 
dad y suspensión ${ }^{14}$. Más bien ocurre lo opuesto; es decir, la confirmación de una dialéctica de décadas entre cuanto constituye un privilegio general y cuanto resulta ser solo una facultad judicial para inutilizarlo exclusivamente ante determinados supuestos, a saber, cuando se cumplan estrictamente los criterios legales para su adopción: que tras una ponderación suficientemente motivada de todos los intereses en conflicto considere que la ejecución del acto puede hacer perder la finalidad al recurso (periculum in mora) o causar perturbación grave a los intereses generales o de terceros ${ }^{15}$.

La paralización cautelar de la actuación administrativa entronca con el viejo principio, sentado por el Tribunal de Justicia de la Comunidad Europea, en virtud del cual "la necesidad del proceso para obtener razón no debe convertirse en un daño para quien tiene la razón"16, lo cual obliga a impedir los abusos a seguir del llamado privilegio de autoejecución, envervando que pueda el poder público parapetarse en él, siempre y cuando -como requisito sine qua non- en un supuesto de hecho concreto lo que se advierte prima facie, sin que ello suponga prejuzgar el pleito principal, es una apariencia de buen derecho ${ }^{17}$. Se trata de evitar la consolidación de situaciones irreversibles que, obviamente, una "indemnización a posteriori" puede no restaurar ${ }^{18}$. La esencia de la tutela cautelar radica, pues, en conciliar la efectividad de la tutela judicial con la eficacia administrativa, un equilibrio tan necesario como difícil de lograr, no en vano la primera exige la urgente adopción, con unos elementos de cognición mínimos, de medidas que pueden tener efectos tan irreversibles como aquéllos que se pretenden evitar ${ }^{19}$. La irreversibilidad

14 LORENZO DE MEMBIELA, J.B.: "La suspensión del acto administrativo en la Ley jurisdiccional de 1998", Revista de Derecho Procesal, núms. 1-3, 2001, págs. 443 y ss.

${ }^{15}$ ATS 12 septiembre 2000 (RJ 282/ 2001) o SAN 11 julio 2007 (JUR 236857).

16 En la conocida Sentencia Factortame, de 19 de junio de 1990, comentada por GARCÍA DE ENTERRÍA, E.: La batalla por las medidas cautelares, cit., págs. 335 y ss.

17 LÓ PEZ-FRAGOSO ÁLVAREZ, T.: "Las medidas cautelares en la nueva Ley de la Jurisdicción Contencioso-Administrativa", Tribunales de Justicia, núms. 8-9, 1999, pág. 731.

18 RODRÍGUEZ-ARANA MUÑOZ, J.F.: “Las medidas cautelares en la jurisdicción contencioso-administrativa en España”, cit., pág. 130.

${ }^{19}$ CHINCHILLA MARÍN, C.: "La tutela cautelar”, en AA.VV (LEGUINA VILLA, J. y SÁNCHEZ MORÓN, M., Dir.): Comentarios a la Ley de Jurisdicción Contencioso-Administrativa, Valladolid, 1999, pág. 569. 
se convierte, así, en el nudo gordiano de la materia que ocupa la atención del presente ensayo. La intensidad en que el interés general exija o no la ejecutividad del acto ha de calibrarse en cada caso concreto, y será el factor determinante en la adopción de las medidas cautelares ${ }^{20}$. Si el fundamento de la ejecutividad del acto administrativo se encuentra en la necesidad de servir con eficacia a los intereses generales, en buena lógica habrá que concluir que el acto administrativo se verá privado de dicha cualidad únicamente cuando aquéllos no exijan su ejecutividad inmediata o si, aun demandándola, la protección cautelar frente al acto sea necesaria para asegurar la efectividad de la sentencia, evitando que el tiempo de duración del proceso termine por privarlo de virtualidad 21 .

En tanto en cuanto el proceso administrativo tiene por objeto una pretensión, deducida por lo general frente a un acto de un Ente público, investido de presunción de legitimidad y, por tanto obligatorio y ejecutivo, una concreta materialización de las medidas precautorias requiere la armonización de dos argumentos en pugna: de un lado, el de la seguridad jurídica, y, de otro, el de la eficacia de la acción administrativa22. De este modo, la paralización precautoria, por los importantes efectos que puede producir en la realidad jurídico-material antes de que el órgano jurisdiccional se pronuncie sobre la conformidad a Derecho de la pretensión, sólo podrá adoptarse si concurren las estrictas circunstancias previstas en el ordenamiento ${ }^{23}$.

De ahí que se le haya atribuido a la suspensión, con todo acierto, la calificación de medida "provisionalísima"24, para así destacar convenientemente

20 ESCUDERO HERRERA, C.: "De la instrumentalidad y otras características de las medidas cautelares en el orden contencioso-administrativo. Especial referencia a la suspensión de las disposiciones y actos", Actualidad Administrativa, núm. 25, 1998, págs. 527 y ss.

21 GIMENO SENDRA, J.V.: “Un nuevo sistema de medidas cautelares en la LJCA de 1998”, en AA.VV (SOSA WAGNER, F., Coord.): EI Derecho Administrativo en el umbral del siglo XXI: homenajeal profesor Dr. D. Ramón M artín M ateo, Valencia, 2000, págs. 2249 y ss.

22 CALVO ROJAS, E.: "Medidas cautelares en el proceso contencioso-administrativo: medidas provisionalísimas y medidas cautelares positivas. Últimos avances en esta materia y algún exceso", Revista Española de Derecho Administrativo, núm. 83, 1994, págs. 465 y ss.

23 GONZÁLEZ PÉREZ, J.: Comentarios a la Ley de la Jurisdicción Contencioso-Administrativa (Ley 29/1998, de 13 de julio), T. II, 3ạ edición, Madrid, 1998, pág. 2038.

24 STSJ Madrid 21 noviembre 2006 (JUR 181932/ 2007). 
cómo únicamente deviene oportuna "cuando el derecho a la tutela judicial efectiva está en riesgo, o lo que es igual, cuando existe urgencia en preservarIo"25; y, aún así, pudiendo denegarla si prevalece el interés público general frente al particular del recurrente, de entender que aquél exige su ejecución incluso durante el proceso, hasta tanto judicialmente se dirima quién tiene razón ${ }^{26}$.

Cabe aludir, de este modo, a que la regla general de la ejecutividad del acto administrativo sigue exigiendo "mesura" a la hora de otorgar la suspensión ${ }^{27}$, para así denominar a cuantos muchos otros consideran necesaria una hermenéutica "estricta" sobre los condicionantes para su concesión ${ }^{28}$. En el camino, y a partir de las premisas dadas, cabe anticipar que la pieza de suspensión encierra necesariamente un test de interpretación a partir del cual es preciso interrogarse sobre si la presunción de corrección del acto establecida en la norma viene acompañada de una apariencia de legalidad en el caso enjuiciado ${ }^{29}$. La cuestión no versa, así, sobre el valor de cuanto firmemente sostienen los arts. 57.1, 94 y 111.1 LRJAP, sino en una aproximación de aquellos preceptos al supuesto sometido a cuestión y a la determinación, a su vista, de si la actividad enjuiciada aparece extrínsecamente revestida de una apariencia merecedora de protección en Derecho ${ }^{30}$. Tal valoración habrá de ser necesariamente sumaria, al objeto de decidir provisionalmente si es razonable proteger hic et nunc el interés general o el sostenido por el recurrente. Es ésta una condición stricto iure cuyos elementos de convicción debe aportar quien insta la aplicación del 130.131.

${ }^{25}$ ATS 8 julio 1997 (RJ 5823).

${ }^{26}$ ATS 3 abril 2001 (RJ 2856).

27 SSTS 16 septiembre 1999 (RJ 7747), 12 septiembre y 7 noviembre 2000 (RJ 282 y 285/ 2007).

28 SSTS 16 septiembre 2006 (TOL 998471) y 27 junio 2007 (RJ 4879), o el muy concluyente ATS 19 febrero 2001 (RJ 2845).

${ }^{29}$ RODRÍGUEZ VÁZQUEZ DE PRADA, V.: “La suspensión como medida cautelar en los procesos contenciosos-administrativos. Principios (el principio de apariencia de buen derecho fumus boni iuris). Una valoración provisional como base de una medida provisional", Revista Española de Derecho Administrativo, núm. 82, 1994, págs. 311 y ss.

30 TORNOS MAS, J.: "Ejecución de sentencias favorables a la Administración y medidas cautelares", Justicia Administrativa, núm. 15, 2002, págs. 23 y ss.

31 TORRES FERNÁNDEZ, J.J.: “Comentario sobre la regulación de las medidas cautelares en la nueva Ley reguladora de la jurisdicción contencioso-administrativa de 13 de julio de 1998", Repertorio de Jurisprudencia Aranzadi, núm. 6, 1999, págs. 91 y ss. 
En fin, e intentando anticipar una definición de las medidas cautelares (y, en concreto, de la tendente a la suspensión del acto), cabe destacar cómo sus notas señeras vienen marcadas por los siguientes extremos: constituyen incidentes de un proceso administrativo, caracterizados por las notas de instrumentalidad y provisionalidad, cuya función consiste en garantizar la efectividad de la sentencia, que, en su caso, estime la pretensión objeto de dicho proceso, para cuya adopción habrán de concurrir los presupuestos de la apariencia del derecho invocado por el actor y el peligro derivado del transcurso del tiempo que cualquier procedimiento exige para su tramitación, el cual puede hacer perder toda utilidad al pronunciamiento que en su día se dicte ${ }^{32}$.

\section{REQUISITOS}

La traslación de al gunos elementos claves en institutos jurídicos de honda raigambre en determinados ordenamientos de los Estados miembros hizo que muy pronto el Consejo de la entonces Comunidad Económica Europea aceptara la posible suspensión judicial de actos administrativos de la organización internacional bajo acreditación de un conjunto de requisitos de necesaria concurrencia para su otorgamiento. Más tarde que pronto España siguió tal senda abierta -y de necesario tránsito- incorporando, con algunas particularidades, aquel acervo ${ }^{33}$. Esbozar éste, y profundizar sobre la normativa y doctrina judicial existente, constituye el siguiente paso fundamental.

\subsection{Breve referencia al ordenamiento comunitario}

El reconocimiento por el Tribunal Constitucional de las medidas cautelares como integrante de la tutela judicial efectiva contó con la indudable inspiración del ordenamiento de la U nión Europea ${ }^{34}$, el cual constituye hoy casi un "ius commune en la materia"35. También los requisitos para su otorgamien-

32 LÓ PEZ-FRAGOSO ÁLVAREZ, T.: "Las medidas cautelares en la nueva Ley de la Jurisdicción Contencioso-Administrativa", Tribunales de Justicia, núm. 8-9, 1999, pág. 734.

33 OSORIO ACOSTA, E.: La suspensión jurisdiccional del acto administrativo, Madrid, 1995, págs. 53 y ss.

${ }^{34}$ AA. VV (ARNALDO ALCUBILLA, E. y FERNÁNDEZ VALVERDE, R., Dirs.) : Jurisdicción contencioso-administrativa (Comentarios a la Ley 29/1998, de 13 de julio, reguladora de la jurisdicción contencioso-administrativa), Madrid, 1998, págs. 1302 y ss.

${ }^{35}$ GARCÍA DE ENTERRÍA, E.: La batalla por las medidas cautelares, cit., pág. 22. 
to quedarán profundamente impregnados por los cuatro que acumulativamente-no, por tanto, de forma alternativa o excluyente- vienen exigiendo, de manera muy estricta, tanto el Consejo de Europa como el Tribunal de Justicia de las Comunidades Europeas ${ }^{36}$. A saber:

1.- La urgencia en relación con el nivel de gravedad y el carácter irreparable del perjuicio alegado. Así se niega sistemáticamente cuando se trata de evitar un daño que, aun suponiendo fuera cierto, puede ser consecuencia inevitable de un proceso que, por atender a un interés útil, llevaría a repercusiones especialmente negativas para otro derecho prevalente ${ }^{37}$.

2.- El fumus boni iuris, entendido en este caso como falta de carencia manifiesta de fundamento que conlleva una probabilidad grande de hacer prosperar el recurso ${ }^{38}$.

3.- Ponderación de los intereses en juego. Al respecto se considera que, aun cuando hubiera sido demostrada la existencia de un perjuicio grave e irreparable, será menester valorar si la suspensión provocaría el efecto de entorpecer la plena eficacia, en tiempo y forma, de una decisión administrativa que perjudicara a la colectividad o a terceros ${ }^{39}$.

4.- Estricta provisionalidad. En este sentido nunca deberá prejuzgar aspectos de hecho o de Derecho que sean objeto de litigio, ni debe neutralizar por anticipado las consecuencias de las resoluciones de desarrollo, tomando en consideración, siempre, "el riesgo de un daño irreversible para los intereses de la Comunidad en el supuesto de concesión de la medida provisional"40.

${ }^{36}$ CAMPOS SÁNCHEZ-BORDONA, M.: "La tutela cautelar de los derechos con origen en el ordenamiento comunitario", en AA.VV (CAM POS SÁNCHEZ-BORDONA, M., Dir.) : M edidas cautelares en la jurisdicción contencioso-administrativa, cit., págs. 69 y ss.

${ }^{37}$ Auto del Presidente del TJCEE de 3 de mayo de 1996, República Federal deAlemania/ Comisión (asunto C-399/ 95, Rec. Pág. I-2441).

${ }^{38}$ Auto del Presidente del TJCEE de 24 de septiembre de 1996, Reino Unido/Comisión (asuntos acumulados C-239/ 96 y C.240/ 96, Rec., pág. II-4475).

${ }^{39}$ Auto del Presidente TJCEE de 12 de julio de 1996, Reino Unido/ Comisión (asunto C-180/ 96, Rec., pág. I-3903).

${ }^{40}$ Auto del Presidente del TJCEE de 25 de junio de 1998, Gobierno de las Antillas Neerlandesas/ Consejo (asunto C-159/ 98). 


\subsection{Su plasmación en el Derecho interno}

No infrecuente resulta, a día de hoy al menos, que los Tribunales españoles acaben reduciendo la cuestión relativa a los criterios para otorgar la suspensión de los actos administrativos en vía judicial prestando exclusiva atención a cuanto previene el art. 130 LJCA para conceder la medida cautelar: hacer perder su finalidad legítima al recurso ${ }^{41}$. Trátase, con todo, de una visión excesivamente simple que, de acuerdo con aquéllos más preocupados por una interpretación completa de la cuestión ${ }^{42}$, la amplían a la exigencia de sopesar los cinco requisitos de obligada concurrencia a continuación analizados ${ }^{43}$.

\subsubsection{La prueba sobre la necesidad de paralización}

En criterio firme del Tribunal Constitucional, acordar o mantener la medida cautelar aquí analizada requiere no sólo la invocación de daños y perjuicios derivados de ejecutar el acto administrativo, sino que "es preciso demostrar 0 , al menos, razonar consistentemente su procedencia y la imposible o difícil reparación de los mismos, ya que debe partirse, en principio, de la existencia de una presunción de constitucionalidad a favor de las normas o actos objeto de conflicto"44. Esto significa que el interesado ha de hacer valer la necesidad de protección jurídica cautelar, es decir, la insuficiencia de los medios ordinarios de tutela jurisdiccional para garantizar su posición jurídica, por ser sólo la medida a adoptar el instrumento idóneo a tal fin ${ }^{45}$.

La apuntada relación dialéctica entre regla general y facultad judicial tiene su razón de ser, para poder actuar esta última, en velar por la posición de la parte que aparentemente litiga con razón y preservar el derecho a la tutela

${ }^{41}$ CO LLADO GARCÍA-LAJARA, E.: "Las medidas cautelares en la nueva Ley de la Jurisdicción Contencioso-Administrativa", La Ley, núm. 6, 1998, págs. 2181 y ss.

42 Extraordinaria la síntesis ofrecida por la STJS Madrid 16 marzo 2006 (RJCA 462).

43 Por extenso, RUIZ PIÑEIRO, F.: Las medidas cautelares en la Ley 29/1998, de 13 de julio, de la jurisdicción contencioso-administrativa: análisis doctrinal y jurisprudencial, Pamplona, 2001, págs. 53 y ss.

44 AATCo 472/ 1988, de 19 de abril; 285/ 1990, de 11 de julio; 266/ 1994, de 4 de octubre; 156/ 1996, de 11 de junio o 282/2001, de 30 de octubre.

45 GONZÁLEZ-VARAS IBÁÑEZ, S.: Comentarios a la Ley de Jurisdicción Contencioso-Administrativa, cit., pág. 959. 
judicial efectiva al final del proceso, para lo cual es necesario que se haya producido acreditación suficiente del daño de la actora en el momento de la vaIoración; no una mera invocación genérica de la existencia de un perjuicio, sino la prueba de la realidad del mismo ${ }^{46}$.

He aquí una cuestión clave a la hora de sopesar uno de los aspectos fundamentales en el marco de análisis afrontado: el interesado en obtener la suspensión "habrá de aportar de manera suficiente y acreditada que concurre la circunstancia habilitante de la misma: su estricta necesidad"47. "No hace falta que sea una prueba completa, basta la incompleta o por indicios de aquellas circunstancias a partir de las cuales permitir al juzgador efectuar la valoración de la medida solicitada"48, pero la exigencia de protección cautelar ha de tener un carácter preciso y determinado, manifestado en perjuicios reales, "no meramente hipotéticos" 49 .

"No es de recibo admitir que prospere la concesión de la medida cuando la pretensión ejercitada no aparezca provista de ningún tipo de fundamento 0 sea notoriamente insuficiente para valorar la procedencia de la misma"50, pues según sentará el Tribunal Supremo51, "la mera alegación, sin prueba alguna, no permite estimar como acreditado que la ejecución del acto impugnado (o la vigencia de la disposición impugnada) le puede ocasionar perjuicios, ni menos que éstos sean de difícil o imposible reparación"52.

\footnotetext{
46 SSTSJ Madrid 24 octubre 2006 (JUR 2007/ 229466), 21 noviembre 2006 (JUR 2007/ 181932) o 20 marzo 2007 (JUR 2007/ 203183).

47 STS 1 septiembre 1999 (RJ 7184). En la doctrina, sirva la remisión a RUIZ PIÑEIRO, F.L.: “Las medidas cautelares en la Ley 29/ 1998, de 13 de julio, de la jurisdicción contencioso-administrativa", en AA.VV (CAMPOS SÁNCHEZ-BORDONA, M., Dir.): M edidas cautelares en la jurisdicción contencioso-administrativa, cit., pág. 324.

48 STS 15 septiembre 2003 (RJ 6474) o STSJ Madrid 16 marzo 2006 (RJCA 462).

49 GONZÁLEZ-VARAS IBÁÑEZ, S.: Comentarios a la Ley de Jurisdicción Contencioso-Administrativa, cit., pág. 561.

50 ST S 1 septiembre 1999 (RJ 7184).

${ }^{51}$ En precedente muy conocido, ATS 3 junio 1997 (RJ 504).

52 STS 15 septiembre 2003 (RJ 6474) o STSJ Madrid 16 marzo 2006 (RJCA 462).
} 
Bajo cualquier circunstancia, será necesaria una "motivación acorde con el proceso lógico efectuado para justificar la adopción de la medida cautelar solicitada" 53 , lo cual pasa por concretar "qué daños y perjuicios de reparación imposible o difícil concurren en el caso para acordar la suspensión, sin que baste una invocación genérica" 54 . "Para que dicha suspensión proceda es necesario que el interesado demuestre que se encuentra en una situación personal o patrimonial de carácter singular, que haga de él especialmente gravosa la realización o cumplimiento del acto administrativo" $" 55$.

\subsubsection{Imposibilidad de prejuzgar el fondo del asunto}

"Las medidas cautelares tienen como finalidad que no resulten irreparables las consecuencias derivadas de la duración del proceso, de modo que su adopción no puede confundirse con un enjuiciamiento sobre el fondo del tema a decidir"56. De este modo, y según sienta el Tribunal Constitucional -y ya consta-, "el incidente cautelar entraña un juicio de cognición limitada en el que el órgano judicial no debe pronunciarse sobre las cuestiones que corresponde resolver en el proceso principal" 57 . Se trata, pues, de un mero juicio provisional e indiciario, realizado por el juzgador antes de acordar la medida con el fin de garantizar que "de concederse la tutela principal ésta pueda llevarse a cabo finalmente en la sentencia con la que termine el proceso" $" 58$.

Por dicho motivo, si "se trae a colación por la parte... argumentos que inciden directamente en dicho ámbito [-el thema decidendi-], al sostener que la disposición general recurrida, en su proceso de evaluación, ha vulnerado el procedimiento legalmente establecido, tal habrá de ser objeto de valoración

\footnotetext{
53 AATS 2 noviembre 2000 (RJ 9844) y 5 febrero, 21 marzo y 25 junio 2001 (RJ 1398, 59144 y 5801).

54 STS 15 septiembre 2003 (RJ 6474) y SSTSJ Madrid 20 julio 2000 (JUR 248920) y 31 enero 2006 (JUR 273251).

55 GONZÁLEZ-VARAS IBÁÑEZ, S.: Comentarios a la Ley de Jurisdicción Contencioso-Administrativa, cit., pág. 561.

56 STSJ Madrid 16 marzo 2006 (RJCA 462).

57 ST Co 48/ 1993, de 8 de febrero.

58 PÉREZ MORALES, M.G.: "Suspensión de la ejecución de un acto administrativo como medida cautelar en el proceso laboral", AS, núm. 5, 2007, pág. 50.
} 
en la sentencia que resuelva el fondo del proceso, pero no en la pieza de suspensión" 59 .

De resolver sobre el mismo "se quebrantaría el derecho fundamental al procedimiento con las debidas garantías de contradicción y prueba" ${ }^{60}$, dado el "riesgo de obtener en fase cautelar lo que es objeto mismo del fondo del asunto..., lo cual desnaturaliza el propio alcance de la suspensión"61, al estarse, en realidad, "ante la estimación anticipada de un eventual recurso contencioso-administrativo, confundiéndose la cuestión cautelar con la litigiosa" 62. No procedería, en consecuencia, la medida cautelar si su concesión supone prejuzgar la decisión final ${ }^{63} 0$, simplemente, si está íntimamente ligada a la cuestión principal debatida64.

\subsubsection{El periculum in mora}

Si lo que legitima la adopción de la medida cautelar es la necesidad de evitar que el recurso pierda su finalidad, y ésta no es otra que otorgar tutela judicial efectiva, lo que efectivamente puede hacer peligrar la efectividad de la tutela que con el recurso se pretende no son, precisamente, los efectos favorables o beneficiosos a seguir de de los actos administrativos para quien la solicita, sino los perjuicios, y además, como mínimo, difíciles de reparar, porque si fueran fácilmente subsanables la efectividad no correría riesgo alguno 65 .

${ }^{59}$ ATS 8 octubre 2004 (JUR 2004/ 280805).

60 STS 14 abril 2003 (RJ 4656).

61 SSTSJ Madrid 2 marzo 2007 (JUR 230562 y 230563).

62 STSJ Comunidad Valenciana 18 julio 2006 (RJCA 298/ 2007).

63 GONZÁLEZ-VARAS IBÁNEZ, S.: Comentario a la Ley de Jurisdicción Contencioso-Administrativa, cit., pág. 562.

64 PERA VERDAGUER, F.: Comentarios a la Ley de lo Contencioso-Administrativo. Ley 29/1998, de 13 de julio, 6ạ edición, Barcelona, 1998, pág. 793.

65 CHINCHILLA MARÍN, C.: "Los criterios de adopción de las medidas cautelares en la nueva Ley reguladora de la jurisdicción contencioso-administrativa", en AA.VV (CAMPOS SÁNCHEZ-BORDONA, M., Dir.): M edidas cautelares en la jurisdicción contencioso-administrativa, cit., pág. 51. 
El periculum in mora aparece así -en principio al menos- como el primer criterio a sopesar para conceder o no la suspensión de la ejecución del acto administrativo, ya sea en su "fórmula clásica de irreparabilidad del perjuicio", ya de advertirse "que, de modo inmediato, puede producirse una situación que haga ineficaz el proceso"66. La inmediata ejecución ha de ocasionar para el recurrente daños o perjuicios de reparación imposible o difícil derivados de la pérdida de la finalidad legítima al recurso, es decir, es precisa la concurrencia de un peligro de grave afectación jurídica para el derecho cuya protección se impetra, derivado del retraso en la emisión del fallo definitivo ${ }^{67}$.

Siendo clara "la instrumentalización de la medida cautelar" en orden exclusivamente a los factores alegados ${ }^{68}$, preciso será descender a su análisis en detalle:

A) La alegación de un perjuicio de difícil o imposible reparación obliga a identificar un daño capaz de provocar "que el restablecimiento del recurrente en el derecho sea tardío y convierta en ilusoria y nominal la sentencia final"69, por no ser "efectiva"70, al hacer inviable el resarcimiento del mal causado. En caso contrario, "nada impediría sustanciar el proceso ni estimar eventualmente la pretensión deducida y reponer la situación de forma que pueda actuarse el derecho", convirtiéndose la reversibilidad de lo actuado en pieza clave para denegar la suspensión si "los daños económicos y personales derivados del impedimento resultan, en principio, resarcibles de prosperar la petición de la parte" 71 .

Según señalan los Tribunales, la recuperación de lo perdido sin mayor complicación, quedando indemne la posición del inicialmente damnificado,

66 STSJ Madrid 16 marzo 2006 (RJCA 462).

${ }^{67}$ AA.VV (ARNALDO ALCUBILLA, E. y FERNÁNDEZ VALVERDE, R., Dir.): Jurisdicción contencioso-administrativa (Comentarios a la Ley 29/1998, de 13 de julio, reguladora de la jurisdicción contencioso-administrativa), cit., pág. 1322.

68 STS 9 marzo 2001 (RJ 2849).

${ }^{69}$ ATS 19 febrero 2001 (RJ 2845).

70 SSTS 16 junio y 4 noviembre 1997 (RJ 5443 y 7974).

71 SAN 28 junio 2006 (JUR 187177). 
al no concurrir situaciones irreversibles que impidan la ejecución de la resolución capaces de causar perjuicios irreparables, hará decaer la posible adopción de la medida cautelar ${ }^{72}$. Si "no se atisba a comprender qué impediría, caso de obtener una sentencia estimatoria, subsanar la anomalía originaria o por qué no sería susceptible su posición jurídica perturbada de compensarse económicamente", no procederá la suspensión ${ }^{73}$. Por tal motivo -y como posteriormente cabrá comprobar-, parece que en los procesos de selección de funcionarios nunca concurriría una "merma del principio de identidad en caso de estimarse el recurso"74, al haberse solventado en otros casos el problema adscribiendo al actor 0 actores de instancia a la plaza que resultara de la declaración judicial y/ o, en última instancia, a partir de una indemnización complementaria o alternativa ${ }^{75}$. Aspecto, este último, fundamental, pues "la Administración, por su propia naturaleza, organización y funcionamiento es una entidad pública y solvente en grado máximo, por lo que la posible existencia de esos perjuicios económicos derivados de la ejecución del acto administrativo que posteriormente fuese anulado en vía jurisdiccional no puede ofrecer, ni ofrece, dificultades en cuanto a la congruente y adecuada reparación de los perjuicios causados, fácilmente conseguible dada la solvencia de los Entes públicos"76.

B) El segundo factor a considerar viene dado porque "el trascurso del tiempo en que ha de desenvolverse el proceso ponga en riesgo el efecto útil de la sentencia"77, "fin último y prioritario del instituto de las medidas cautelares"78, habida cuenta si "en un período muy limitado se resolviera sobre el fondo no procedería la suspensión"79. La tutela jurisdiccional no será efectiva

\footnotetext{
72 STS 18 noviembre 2003 (RJ 8180) o SAN 16 octubre 2003 (JUR 53540/ 2004).
}

73 STSJ Castilla y León/ Burgos 18 marzo 2005 (JUR 226923).

${ }^{74}$ AATS 2 noviembre 2000 (RJ 9844) ó 5 febrero, 21 marzo y 25 junio 2001 (RJ 1398, 5914 y 5803).

75 AATS 19 enero y 15 marzo 1999 (Ar. 1494 y 2797).

76 STS 19 marzo 1997 (RJ 1872).

77 STS 18 noviembre 2003 (RJ 8180).

78 SSTS 16 junio y 4 noviembre 1997 (RJ 5443 y 7974).

${ }^{79}$ SAN 11 julio 1997 (JUR 236852). 
si, al pronunciarse el fallo judicial, resulta difícil o prácticamente imposible la satiffacción de la pretensión, razón por la cual deviene necesario arbitrar mecanismos que garanticen frente a ese riesgo. De ahí el carácter instrumental de las medidas cautelares, accesorio respecto de otro proceso al cual se atribuye la condición de principal ${ }^{80}$.

\subsubsection{La ponderación de los intereses concurrentes}

La LJCA insiste en "una previa valoración de las circunstancias de todos los intereses en conflicto", en clara referencia al "principio de proporcionalidad". En este caso eje clave en la materia aquí tratada ${ }^{81}$, no en vano procederá tomar en consideración "no sólo en qué medida la justicia cautelar es precisa para garantizar los derechos de quien la pide, sino también en qué modo puede incidir en la tutela de otros intereses, tanto generales como de tercero"82.

El juicio cautelar es necesariamente ponderativo, estando llamado a alcanzar un difícil equilibrio entre los intereses en liza, en el cual obligatoriamente tendrá que calibrarse si otras expectativas distintas de las del sujeto que solicita la tutela cautelar, pero igualmente dignas de protección, pueden sufrir como consecuencia de la adopción de la medida ${ }^{83}$. El alcance que deba darse a esos otros intereses en relación con el que defiende la parte solicitante no puede ser definido a priori, ni en el sentido de hacerlos prevalecer sobre la medida cautelar instada, ni tampoco en el de llevarlos a ceder, pero lo que no cabe, en ningún caso, es prescindir de su toma en consideración ${ }^{84}$. Es decir, la "ejecutividad del acto" no puede alegarse en el proceso, unida a la presunción de su validez iuris tantum, como motivo de oposición a la práctica de la medida cautelar, sino que la prevalencia del "interés público" en colisión con otros generales o privados en conflicto debe justificarse (en el propio procedimien-

80 GONZÁLEZ PÉREZ, J.: Comentarios a la Ley de la Jurisdicción Contencioso-Administrativa (Ley 29/1998, de 13 de julio), 3a edición, cit., pág. 2019.

81 GONZÁLEZ-VARAS IBÁÑEZ, S.: Comentarios a la Ley de Jurisdicción Contencioso-Administrativa, cit., pág. 560 .

82 GIL IBÁÑEZ, J.L.: L as medidas cautelares en el proceso contencioso-administrativo. Una visión práctica, Madrid, 2001, pág. 39.

83 GO NZÁLEZ-VARAS IBÁÑEZ, S.: “M edidas cautelares y jurisdicción contencioso-administrativa", Revista de Derecho Procesal, núm. 1-3, 2001, págs. 199 y ss.

${ }^{84}$ CHINCHILLA MARÍN, C.: “Los criterios de adopción de las medidas cautelares en la nueva Ley reguladora de la jurisdicción contencioso-administrativa", cit., pág. 54. 
to incidental) en circunstancias determinantes de su "preponderancia" y de su "grave perjuicio" en el caso concreto ${ }^{85}$.

Es tan obvio que el juicio cautelar no puede ser sino el resultado de la vaIoración de todos los intereses en presencia, que la regla establecida en la LJCA es especialmente oportuna ${ }^{86}$, no en vano este criterio "es complementario del de la pérdida de la finalidad legítima del recurso" 87 o, de preferirlo, acaba por completarlo88.

Acudiendo -aun a riesgo de ser reiterativos- a los términos del Tribunal Constitucional, "sobre este tipo de incidentes de suspensión existe una consolidada doctrina, según la cual para su resolución es necesario ponderar, de un lado, los intereses en pugna, tanto el general y público como el particular o privado de las personas afectadas; y, de otro, los perjuicios de difícil o imposible reparación que se irrogan del mantenimiento o levantamiento de la suspensión. Esta valoración debe efectuarse mediante el estricto examen de las situaciones de hecho creadas y al margen de la viabilidad de las pretensiones que se formulan en la demanda"89.

Sobre tal hipótesis, "la tensión entre los principios de efectividad de la decisión judicial y los de eficacia administrativa (arts. 24.1 y 103.1 CE) ha de solucionarse a base de ponderar casuísticamente su preeminencia o prevalencia en vista de la dificultad de fijar reglas generales"90; régimen en el cual queda

85 RODRÍGUEZ-ARANA MUÑOZ, J.F.: “Las medidas cautelares en la jurisdicción contencioso-administrativa en España", cit., núm. 28, 2006, pág. 242.

${ }^{86}$ CASTILLO BLANCO, F.A.: "La nueva regulación de las medidas cautelares en la Ley de la Jurisdicción Contencioso-Administrativa de 1998", Revista del Poder Judicial, núm. 52, 1998, págs. 283.

87 STSJ Madrid 16 marzo 2006 (RJCA 462).

88 DE LA ROSA HERRERO, T.: “Comentarios a propósito de las medidas cautelares en la Ley 29/ 1998, de 13 de julio, reguladora de la jurisdicción contencioso-administrativa", Actualidad Administrativa, núm. 34, 2000, pág. 1007.

${ }^{89}$ AATCo 472/ 1988, de 19 de abril; 285/ 1990, de 11 de julio; 266 y 267/ 1994, de 4 de octubre y 156/ 1996, de 11 de junio.

90 AATS 6 y 23 abril 1999 (RJ 4361 y 4645), 2 noviembre, 21 marzo y 21 junio 2001 (RJ 1398, 5914 y 5801) ó 12 febrero 2002 (RJ 807). 
un "indudable margen de discrecionalidad"91. Como con acierto se ha dicho, "el casuismo es la regla, (no en vano) la naturaleza del acto y las circunstancias concurrentes exigen siempre y en todo caso una valoración pormenorizada"92.

No se trata ya del interés público genérico, que se presupone es el fin de todo acto administrativo, capaz de justificar la presunción de legitimidad y, por ende, su ejecutoriedad. Si así fuera, apenas si podría decretarse la suspensión de la ejecución ${ }^{93}$. "Cuando se establece que la suspensión no puede decretarse frente al interés público prevalente se está pensando en algo mucho más concreto. Se está pensando en que en aquel supuesto en el cual se plantea la suspensión, el interés público está exigiendo precisamente el cumplimiento del acto"94. Eso sí, singularidad pero siempre sobre una máxima, "que reitera hasta la saciedad la jurisprudencia: cuando las exigencias de ejecución que el interés público presenta son tenues bastarán perjuicios de escasa entidad para provocar la suspensión; por el contrario, cuando aquella exigencia es de gran intensidad, sólo perjuicios de elevada consideración podrán determinar la suspensión de la ejecución del acto"95.

Por tal motivo, se percibe y declara expresamente que "llegado el momento de sopesar el interés público y el particular a la hora de acceder, o no, a la suspensión de las resoluciones impugnadas dentro de un recurso contencioso administrativo, habitualmente se viene a dar prevalencia al general"96, cediendo tal pauta únicamente cuando media una grave afectación del acto administrativo a otro interés público comprometido y a los intereses de terceras personas ${ }^{97}$, a entender como daños o perjuicios impeditivos y gravemente

91 PERA VERdAGUeR, F.: Comentarios a la Ley de lo Contencioso-Administrativo. Ley 29/1998, de 13 de julio, cit., pág. 793.

92 LORENZO DE MEMBIELA, J.B.: "La suspensión de la ejecución del acto administrativo en la Ley Jurisdiccional de 1998", Actualidad Administrativa, núm. 19, 2001, pág. 796.

93 ESPINOSA DE RUEDA JOVER, M.: "Las medidas cautelares en el proceso contencioso-administrativo", Actualidad Administrativa, núm. 20, 1999, pág. 587.

94 GONZÁLEZ PÉREZ, J.: Comentarios a la Ley de Jurisdicción Contencioso-Administrativa (Ley 29/1998, de 13 de julio), cit., pág. 2049.

95 AATS 3 junio 1997 (RJ 5049) y 12 julio 2000 (RJ 5357); enormemente clarificadoras las SSTSJ Cataluña 8 abril y 16 diciembre 2005 (JUR 172638 y JUR 2006/ 85820).

96 STS 24 abril 1998 (RJ 3428) o SSTSJ Madrid 2 marzo 2007 (JUR 230562 y 230563).

97 SSTS 16 junio y 4 noviembre 1997 (RJ 5443 y 7974). 
obstaculizadores del disfrute de un derecho fundamental ${ }^{98}$.Expresa referencia al fumus boni iuris, cuya aplicación queda confiada a la jurisprudencia y al efecto reflejo de la LEC/ 2000, que sí alude al mismo en el art. 728"103.

Por este motivo, algunos Tribunales de Justicia son tajantes en su posición de "desechar, en primer lugar, el criterio del fumus boni iuris, pues el art. 130.1 LJCA lo sustituye por el atinente a que la ejecución del acto o la aplicación de la disposición pudieran hacer perder su finalidad legítima al recurso"104. Este precepto utiliza la expresión 'únicamente', que puede entenderse, bien en el sentido [-ya significado páginas atrás-] del carácter excepcional de las medidas cautelares frente a la regla general del privilegio de la ejecutividad del acto administrativo y del carácter no suspensivo del recurso, bien en el sentido de que la adopción de tales medidas sólo procede en el supuesto previsto por la norma, es decir, cuando sean precisas... para garantizar la efectividad de la sentencia. En este último sentido, la norma del art. 130.1 LJCA impide considerar criterios distintos al que enuncia para justificar la adopción de medidas cautelares y, principalmente, el fumus boni iuris, según el cual para resolver sobre la adopción de la medida cautelar que la suspensión implica resulta obligada la ponderación, aun en la fase inicial del proceso, de las posiciones de las partes, debiendo otorgarse aquélla al recurrente cuando sustenta una postura que aparentemente se presenta como justa... Resulta significativo, a este respecto, que el art. 124.2 del Proyecto de LJCA dijese que 'la adopción de medidas cautelares podrá acordarse cuando existan dudas razonables sobre la actividad administrativa de que se trata' y que dicho texto no conste incorporado a la LJCA"105.

${ }^{98}$ STSJ Madrid 21 noviembre 2006 (JUR 181932/ 2007).

${ }^{99}$ AATS 2 noviembre 2000 (RJ 9844) o 4 diciembre 2001 (RJ 211/ 2002).

100 STS 12 junio 2001(RJ 6097) y STSJ Castilla y León/ Valladolid 7 febrero 2006 (JUR 82786).

101 En concreto, a través del famoso ATS 20 diciembre 1990 (RJ 10412).

102 GONZÁLEZ PÉREZ, J.: Comentarios a la Ley de la Jurisdicción Contencioso-Administrativa (Ley 29/1998, de 13 de julio, cit., pág. 2045.

103 STSJ Madrid 16 marzo 2006 (RJCA 462).

104 CAMPOS SÁNCHEZ-BORDONA, M.: "Reflexiones sobre algunos problemas que plantea el nuevo régimen de las medidas cautelares en la Ley reguladora de la Jurisdicción Contencioso-Administrativa", Revista de Administración Pública, núm. 149, 1999, págs. 110 y ss.

105 SST SJ Comunidad Valenciana 20 mayo 2003 (JUR 23534/ 2004) o 17 octubre 2005 (JUR 107758/2006). 
La reseñada constituye una reacción radical contra la jurisprudencia sobre la probabilidad de que el resultado del proceso sea favorable al actor, ratificada expresamente poco antes del cambio legal, cuando consideró que "sigue resultando pertinente la aplicación del principio de prevalencia en la tutela de la apariencia de buen derecho"106. Frente a ella cabía oponer antes, y más aún ahora, bajo el nuevo tenor normativo, que efectivamente se trata de una doctrina "tan difundida, como necesitada de prudente aplicación"107.

La razón para tal Ilamada a la cautela es que el criterio del fumus boni iuris "entraña, por sí mismo, un examen sobre el fondo del asunto que no es susceptible de ser tratado, por lo general, en una pieza de suspensión"108. En virtud de la anterior premisa, esta doctrina, "que permite valorar con carácter provisional, dentro del limitado ámbito que incumbe a los incidentes de esta naturaleza y sin prejuzgar lo que en su día declare la sentencia definitiva, los fundamentos jurídicos de la pretensión a los meros fines de la tutela cauteIar"109, siempre fue aceptada con reservas firmes. Éstas se asentaban en cuanto cabe considerar un principio y sus excepciones ${ }^{110}$.

La regla venía -y viene- dada por considerar que no cabrá su invocación de "predicarse la nulidad de un acto que ha de ser, por primera vez, objeto de valoración y decisión, pues, de lo contrario, se prejuzgaría la cuestión de fondo, de manera que por amparar el derecho a la efectiva tutela judicial, se vulneraría otro también fundamental y recogido en el propio art. $24 \mathrm{CE}$, cual es el derecho al proceso con las garantías debidas de contradicción y prueba, porque el incidente de suspensión no es el trámite idóneo para decidir la cuestión objeto del pleito"111.

106 SSTS 16 junio y 4 noviembre 1997 (RJ 5443 y 7974).

107 SSTS 4 enero 1997 (RJ 129) y 14 abril 2003 (RJ 4656) o AATS 22 noviembre 1993 (RJ 8943), 7 noviembre 1995 (RJ 8134) y 26 noviembre 2001 (RJ 4176).

108 AATS 21 julio, 14 noviembre y 1 y 9 diciembre 1997 (RJ 6111, 8070, 8910 y 9070).

109 STSJ Madrid 16 marzo 2006 (RJCA 462).

110 GARCÍA DE ENTERRÍA, E.: "La nueva doctrina del Tribunal Supremo sobre medidas cautelares: la recepción del principio del fumus boni iuris", Revista Española de Derecho Administrativo, núm. 69, 1991, págs. 65 y ss.

111 STS 14 enero 1997 (RJ 129); SAN 28 junio 2006 (JUR 187177) o AATS 22 noviembre 1993 (RJ 8943), 7 noviembre 1995 (RJ 8134) y 26 noviembre 2001 (RJ 4176). 
No obstante lo expuesto, el criterio de la buena apariencia puede seguir operando, siempre teniendo presente la necesaria llamada a la mesura, en supuestos muy excepcionales y concreto ${ }^{112}$, a saber, aquéllos en los cual es sea "ostensible la prosperabilidad de la demanda, por tratarse de una nulidad patente, manifiesta y evidente a todas luces"113, o cuantos quedan referidos "a la impugnación de un acto idéntico a otro que ya fue anulado jurisdiccionalmente y constan, por tanto, sólidos antecedentes para casos iguales en los cuales hubieran sido dictadas sentencias estimatorias de los respectivos recursos"114.

Así pues, a pesar de la ausencia de referencias explícitas a la apariencia de buen derecho en la LJCA, parece que ha de considerarse que el órgano jurisdiccional no puede abstenerse de tener presente este presupuesto en los supuestos mencionados, pues no hay nada que se lo impida en la nueva regulación, aun cuando, es claro, "no como criterio determinante, pues el no considerar la necesidad de que en el caso concreto concurra el presupuesto del fumus boni iuris, y sí únicamente el periculum in mora, llevaría en muchas situaciones a una desmesurada aplicación de las medidas cautelares"115. "El presupuesto del fumus debe ser atendido y aplicado como un elemento de apoyo a situaciones claras que predispongan a la racional creencia de que el recurso ha de prosperar, no pudiendo ser por sí solo causa última de la suspensión de los actos administrativos recurridos, sino criterio complementario con el principal de la existencia de daños y perjuicios de imposible o difícil reparación, requisito este fundamental y básico"116.

Esta doctrina sobre los límites de la operatividad del fumus boni iuris exige aclarar los siguientes extremos: una vez más la racionalidad viene a demandar que el criterio de la apariencia de buen derecho no sea tomado como

112 ATS 5 diciembre 2000 (RJ 286/2001).

${ }^{113}$ AATS 21 julio, 14 noviembre y 1 y 9 diciembre 1997 (RJ 6111, 8070, 8910 y 9070).

114 SST S 14 abril 2003 (RJ 4656); SAN 28 junio 2006 (JUR 187177) o AATS 22 noviembre 1993 (RJ 8943), 7 noviembre 1995 (RJ 8134), 5 diciembre 2000 (RJ 286/ 2001) o 26 noviembre 2001 (RJ 4176).

115 LÓ PEZ-FRAGOSO ÁLVAREZ, T.: "Las medidas cautelares en la nueva Ley de la Jurisdicción Contencioso-Administrativa", Tribunales de Justicia, núm. 8-9, 1999, pág. 740.

${ }^{116}$ AA.VV (ARNALDO ALCUBILLA, E. y FERNÁNDEZ VALVERDE, R., Dirs.) : Jurisdicción contencioso-administrativa (Comentarios a la Ley 29/1998, de 13 de julio, reguladora de la jurisdicción contencioso-administrativa), cit., pág. 1325. 
presupuesto fundamental para la adopción de las medidas cautelares, por la sencilla razón de que la tutela precautoria es un instrumento de la efectividad de la tutela judicial, lo cual significa que su adopción se justifica cuando es necesario preservar la efectividad frente al peligro que para la misma pueda implicar la demora del proceso117. Ahora bien, siendo cierto que, como ha manifestado el Tribunal Supremo, "la institución cautelar no tiene por finalidad propia y directa la de tutelar provisionalmente la posición jurídica de la parte que aparentemente litiga con razón, sino preservar el derecho a la tutela judicial efectiva al final del proceso ${ }^{118}$, no lo es menos que "de la misma forma que la intensidad con la que el interés general reclama la ejecución de un acto debe ser tenida en cuenta por los Tribunales para determinar la intensidad del perjuicio que se exige para adoptar la medida cautelar, la intensidad con que se manifieste la apariencia de buen derecho, que es tanto como decir la apariencia de ilegalidad del acto administrativo, debe también tomarse en consideración para determinar la medida del daño que cabe exigir para apreciar la existencia del periculum in mora necesario para otorgar la medida cautelar solicitada"119. El fumus boni iuris, prudentemente utilizado, contribuirá a depurar el proceso de toda manipulación fraudulenta o abusiva, no en vano el principio de la buena fe se impone en todo tipo de actuación judicial ${ }^{120}$.

En definitiva, las medidas cautelares deberán acordarse, o en su caso denegarse, mediante una labor de ponderación por parte del órgano jurisdiccional de todos los intereses en conflicto (tal y como exige el art. 130 LJCA), teniendo en cuenta la verosimilitud del derecho del actor, en contraposición con la presunción de validez de los actos de la Administración, "presunción que puede combatir el demandante precisamente mediante la apariencia de su derecho, para cuya tutela judicial efectiva y en aras a garantizar la efectividad de la sentencia definitiva, se exige la adopción de la tutela cautelar solicitada,

117 CHIN CHILLA MARÍN, C.: “Medidas cautelares”, Revista Española de Derecho Administrativo, núm. 100, 1998, pág. 875.

118 SSTS 17 junio y 1 diciembre 1997 (Ar. 5444 y 8911).

119 CHINCILLA MARÍN, C.: "Los criterios de adopción de las medidas cautelares en la nueva Ley reguladora de la jurisdicción contencioso-administrativa", cit., pág. 58.

120 FENOR DE LA MAZA Y CORNIDE-QUIROGA, A.: Nuevas perspectivas en el proceso contencioso-administrativo. Las medidas cautelares, Madrid, 1997, pág. 350. 
siempre y cuando no se acredite por la parte demandada la concurrencia de un interés general que sería perturbado gravemente si ésta se adoptara"121.

\section{LA APLICACIÓN DE LOS REQUISITOS EXIGIDOS PARA LA SUSPENSIÓN CAUTELAR EN LOS PROCESOS DE SELEC- CIÓN DE FUNCIONARIOS}

$\mathrm{Si}$, conforme ya consta, la valoración objetiva -no meramente subjetiva- y circunstanciada de todos los elementos determinantes del pleito es fundamental en la adopción de las medidas cautelares, esta afirmación se pone de relieve de una manera más gráfica al descender desde el plano general a los sectores concretos del ordenamiento. Abocados, ya se sabe, a un necesario casuismo en la ponderación de los intereses concurrentes, el elemento dado por el ámbito, la materia y las circunstancias en el cual se insta la suspensión cautelar cobra un elevado protagonismo, permitiendo descubrir distintas corrientes judiciales según el ámbito donde actúa la Administración: obras públicas o privadas, extradición de extranjeros ilegales, deudas tributarias o, por no seguir, función pública; incluso dentro de esta última difieren de manera apreciable, por ejemplo, los pronunciamientos relativos a sanciones disciplinarias o a las vías destinadas a la provisión de puestos de trabajo.

De prestar atención, como es menester, a los procesos de selección de funcionarios públicos, procede entrar a considerar las tres cuestiones siguientes:

\subsection{El debido respeto a los principios de mérito y capacidad}

La posición de poder público de la Administración debe primar a la hora de dotarse de los medios humanos necesarios para ejercer su misión, y tal rango ha de encontrar traducción en un proceso minuciosamente reglado para decidir no sólo cuántas personas necesita y el momento en el cual las precisa, sino también quiénes han de ser los elegidos ${ }^{122}$.

Ahora bien, para acceder a la condición de funcionario, a través de una relación de servicios profesionales y retribuidos regulada por el Derecho Ad-

121 LÓPEZ-FRAGOSO ÁLVAREZ, T.: “Las medidas cautelares en la nueva Ley de la Jurisdicción Contencioso-Administrativa", cit., pág. 739.

122 FERNÁNDEZ DOMíNGUEZ, J.J. y RODRÍGUEZ ESCANCIANO, S.: El acceso al empleo público, Madrid, 2005, pág. 17. 
ministrativo (art. 9 Ley 7/ 2007, de 12 de abril, por la que se aprueba el Estatuto Básico del Empleado Público -EBEP-), es imperativo superar un proceso selectivo efectuado a partir de criterios objetivos, no en vano todos los ciudadanos son iguales ante la ley y en su aplicación, de manera que los poderes públicos no pueden expresar preferencias discriminatorias o fundadas en razones subjetivas de unos so bre otros. Dichas pautas neutras deben asentarse, además, en los parámetros de mérito y capacidad, verdaderos índices de una gestión eficaz del interés de la comunidad ${ }^{123}$.

Estos principios reconocidos en los arts. 23.2 y 103.3 CE y -con la importancia que merecen- en el actual art. 55 EBEP, son, por tanto, "los pilares de la configuración de una función pública profesional, imparcial en sus actuaciones y siempre orientada al servicio, con objetividad, de los intereses generales"124. Adoptada la decisión, dotados los medios para proveer nuevos puestos de funcionarios y efectuada la convocatoria por el órgano competente (art. 9 Real Decreto 364/ 1995, de 10 de marzo), es en la selección de quienes van a merecer tal condición donde actúan, sin exclusión alguna posible (ni siquiera en el caso de la especie atípica de los funcionarios interinos, a pesar de que excepcionalmente y con carácter transitorio haya sido modalizado y moderado su rigor ${ }^{125}$ ), las exigencias constitucionales de igualdad, mérito y capacidad (merits system) ${ }^{126}$, a las cuales el Tribunal Constitucional une otra más, la de publicidad ${ }^{127}$.

Procede interpretar, no obstante, cómo la igualdad (que sirve fielmente a las ideas de integración y actuación democrática en lo público, garantía de la necesaria imparcialidad en los elegidos y eficacia administrativa ${ }^{128}$ ) no otor-

123 GARCÍA-TREVIJANO GARNICA, E.: "Consideraciones en torno al derecho de igualdad en el acceso a la función pública”, Revista de Administración Pública, núm. 121, 1990, pág. 249.

124 PUERTA SEGUIDO, F.: La consolidación del empleo público precario, Valladolid, 2003, pág. 84.

125 ST Co 27/ 1991, de 14 de febrero.

126 LORENZO DE MEMBIELA, J.B.: El acceso y la provisión de puestos de trabajo en la Administración Pública, Pamplona, 2005, pág. 83.

127 STCo 85/ 1983, de 25 de octubre.

${ }^{128}$ AGUILAR LUQUE, L. y GONZÁLEZ AYALA, Ma.D.: “El art. 23.1 y 2. El derecho a participar en los asuntos públicos", en AA.VV (ALZAGA VILLAAMIL, O., Dir.): Comentarios a las L eyes Políticas: Constitución Española de 1978, Madrid, 1985, págs. 649 y ss.; PALOMAR OLMEDA, A.: "La configuración constitucional del derecho de acceso a las funciones públicas", Revista de las Cortes Generales, núm. 25, 1992, págs. 87-132; LÓ PEZ FRÍA, A.: "El derecho de acceso a las funciones y 
ga, ex art. 23.2 CE, el derecho a ocupar o desempeñar tareas específicas, sino simplemente a participar (cuando sea menester), bajo las mismas condiciones, en las pruebas de selección ${ }^{129}$; lo hace, además, de forma concluyente, concediendo un derecho subjetivo de carácter fundamental y contenido específico ( "no, por tanto, uno más, sino la auténtica vertiente subjetivizada de toda la estructura democrática del Estado"130), "y diferente al reconocido a los cargos directivos"131. Así, lejos de poderlo considerar una mera especificación del art. 14 CE, lleva a una relación regla general/ particular en la cual precisamente lo primero va a ser el respeto a las condiciones del art. $23.2 \mathrm{CE}$, mientras el art. 14 sólo actúa como referente especial sobre el número de supuestos tasados que expresamente contempla132: "aun cuando el derecho consagrado en el art. 23.2 es una especificación del derecho a la igualdad (art. 14 $\mathrm{CE}$ ), es incuestionable el mayor alcance y operatividad de aquél en su proyección al régimen jurídico funcionarial"133.

El compromiso enunciado en el art. 23.2 CE va a encontrar traducción, de este modo, en la exigencia de unas condiciones objetivas iguales para que todos los ciudadanos puedan acceder a esa situación (también en momentos ulteriores relativos a la provisión de un cargo o puesto de trabajo, singular-

cargos públicos", en AA.VV.: L os derechos fundamentales y libertades públicas. XIII Jornadas de Estudio. Dirección General del Servicio Jurídico del Estado, T. II, Madrid, 1993, págs. 1607-1631; MARI, A.: ACceso e carriera nelle pubbliche amministrazioni, Milán, 1996, especialmente págs. 72 y ss. o PULIDO QUECEDO, M.: El acceso a los cargos y funciones públicas (Un estudio del artículo 23.2 de la Constitución), Madrid, 1991, págs. 42-52.

129 SSTCo 50/ 1986, de 23 de abril; 67/ 1989, de 18 de abril; 200/ 1991, de 28 de octubre; 217/ 1992, de 1 de diciembre; 293/ 1993, de 18 de octubre; 38/2004, de 11 de marzo o 31/ 2006, de 1 de febrero. En el mismo sentido, STS 14 febrero 2003 (Ar. 911).

130 SANTAMARÍA PASTOR, J.A.: “Comentario al art. 23 de la Constitución", en AA.VV (ALZAGA VILLAAMIL, O., Dir.): Comentarios a las Leyes Políticas. Constitución Española de 1978, cit., pág. 293.

131 Anticipando el sentido último y verdadero del precepto, por su claridad y la contundencia de sus argumentos, SÁNCHEZ MORON, M.: "Comentario al art. 23.2 de la Constitución", en AA.VV (ALZAGA VILLAAMIL, O., Dir.): Comentario a las Leyes Políticas: Constitución Española de 1978, cit., págs. 673-674.

132 ARROYO YANES, L.M.: La carrera administrativa de los funcionarios públicos, Valencia, 1994, pág. 200.

133 FERNÁNDEZ FARRERES, G.: "EI principio de igualdad en el acceso a la función pública y en la provisión de puestos de trabajo", en AA.VV.: Función pública, Madrid, 1993, págs. 56-57. 
mente en los concursos de traslados ${ }^{134}$ y en la permanencia sin perturbaciones ilegítimas en el desempeño de su plaza, de conformidad con lo dispuesto en las leyes ${ }^{135}$ ), llevando a excluir o admitir determinadas conductas en atención a la arbitrariedad o razonabilidad -respectivamente- de las pautas de conexión eventualmente fijadas para atender como conviene a la diversidad de tareas a realizar por la Administración ${ }^{136}$ ( con carácter general, pero también en cada una de sus especies ${ }^{137}$ ), las cuales admiten el trato diferenciado de unos aspirantes frente a otros siempre y cuando no conduzca a la discriminación; circunstancia que por sí sola no puede ser presumida, en tanto no parece desproporcionado pensar en el establecimiento de determinados requisitos previos en atención a aquella diversidad funcional significada ${ }^{138}$.

Formulado de otra manera, y a partir de dicho referente, "exige permitir la participación de todo ciudadano en los procedimientos selectivos para el empleo público, sin establecer requisitos o condiciones subjetivas, irrazonables o desproporcionadas capaces de generar discriminación (igualdad de oportunidades); [ también, y] en segundo término, que los elegidos sean los candidatos más capacitad os y meritorios ( no en cambio, que éstos lo sean necesariamente, pues el proceso puede quedar desierto sin merma del principio, sino tan sólo su no preterición)"139. En fin, según se ha dicho con acierto, "el mérito y la capacidad son los principiosjurídicos que están incorporadosal de-

134 SST Co 75/ 1983, de 3 de agosto; 15/ 1988, de 10 de febrero; 47/ 1989, de 21 de febrero o 4/ 1991, de 14 de enero.

135 SST Co 76 y 133/ 1989, de 29 de abril y 19 de julio.

136 GARCÍA-TREVIJANO GARNICA, E.: "Consideraciones en torno al derecho a la igualdad en el acceso a la función pública", cit., pág. 524.

137 Baste remitir a las apreciaciones formuladas por CARRILLO BARROSO, E.: Gestión de re cursos humanos, presupuestación y Hacienda Local en España, Madrid, 1991, pág. 78 o CASTILLO BLANCO, F.A.: Acceso a la función pública local (políticas selectivas y control jurisdiccional), Granada, 1993, pág. 17.

138 SÁNCHEZ BLANCO, A.: "La discrecionalidad técnica de los tribunales de oposiciones y concursos", Revista Española de Derecho Administrativo, núm. 30, 1981, págs. 206-207 o PULIDO QUECEDO, M.: "Algunas consideraciones sobre el acceso a cargos y funciones públicas", Revista Española de Derecho Constitucional, núm. 30, 1990, págs. 176 y ss.

139 SÁNCHEZ MORÓN, M.: Derecho de la Función Pública, 4ạ edición, Madrid, 2004, pág. 124. 
recho fundamental de acceso a la función pública en condiciones de igualdad... Para la Administración son los únicos criterios de selección utilizables, debiendo concretar su contenido en cada caso con el objetivo de dar cumplimiento a la doble finalidad de escoger a los más idóneos y garantizar la igualdad en el proceso. Y para los Tribunales son conceptos jurídicos indeterminados, cuyo control es obligado a la hora de dilucidar si ha sido lesionado o sacrificado indebidamente un derecho fundamental" ${ }^{\prime 140}$.

Sin embargo, los mencionados parámetros constitucionales no siempre son observados con fidelidad. El empleo público es, para el conjunto de la población activa, un bien relativamente escaso, y obtenerlo da lugar a una situación que normalmente viene a ser considerada ventajosa, sobre todo por la estabilidad que garantiza - un trabajo para toda la vida-en comparación con la ocupación en el sector privado. Por tal razón, sobre el acceso a la condición de funcionario gravita el riesgo de clientelismo político o sindical, de endogamias corporativas o académicas, de nepotismo y de otras formas de favoritismo y discriminación, con violación de los estándares constitucionales ${ }^{141}$. Así, la ordenación de actos destinados a materializar quiénes acreditan más méritos y capacidad puede adolecer, en opinión de algunos, de importantes vicios derivados del establecimiento de fórmulas manifiestamente discriminatorias ${ }^{142} 0$ perjudiciales a sus intereses particulares, al establecer diferencias no justificadas entre los distintos aspirantes ${ }^{143}$. Como es lógico, la práctica activa del procedimiento de selección entra dentro del concepto de "actos administrativos" que, como tal, pueden incurrir en infracciones determinantes de su ilegalidad, razón por la cual son recurribles ante los Juzgados y T ribunales de lo contencioso-administrativo (en su caso tras el agotamiento de la vía previa) ${ }^{144}$, sin que nada impida plantear una posible suspensión cautelar de sus efectos.

140 FÉREZ FERNÁNDEZ, M.: "Reflexiones sobre la necesaria renovación del modelo de selección en las Administraciones Públicas", en AA.VV.: Jornadas sobre la selección de personal en las Administraciones Públicas (Vitoria-Gasteiz, 1996), O ñati, 1997, pág. 57.

141 SÁNCHEZ MORÓN, M.: "Acceso al empleo público y adquisición de la relación de servicios", en AA.VV (SÁNCHEZ MORÓN, M., Dir.): Comentarios a la Ley del Estatu to Básico del Empleado Público, Valladolid, 2007, pág. 396.

142 SSTCo 143/ 1987, de 23 de septiembre o 93 y 269/ 1995, de 19 de junio y 3 de octubre.

143 SST Co 193/ 1987, de 9 de diciembre y 33/ 1993, de 29 de noviembre.

144 SÁNCHEZ MORÓN, M.: Derecho de la Función Pública, cit., pág. 149. 


\subsection{Detalle de supuestos concretos}

Cierto es que contra las resoluciones y actos de los órganos administrativos en los procesos de selección (incluidos los de mero trámite) podrá interponerse recurso tanto en vía administrativa como judicial. No menos ciertas resultan las graves disfunciones que puede originar la estimación judicial, siempre tardía, de los recursos en esta materia, sobre todo cuando se trata de procesos selectivos en los cuales participan cientos o miles de aspirantes, quienes quedan sumidos en la inseguridad, no siendo fáciles de resolver tampoco los problemas originados por la revocación de los nombramientos efectuados desplazando a unos funcionarios por otros ${ }^{145}$. La importancia de la suspensión cautelar en esta materia no puede ser, pues, minusvalorada.

La solicitud de esta medida precautoria en los procesos de reclutamiento de mano de obra plantea un importante conflicto jurídico en tanto -según regla repetida de forma constante- debe ponderarse el interés público y el particular de los afectados ${ }^{146}$. El carácter revisor de la jurisdicción de lo contencioso y el principio de autotutela administrativa conlleva una primera y lógica consecuencia: "si se solicita la suspensión cautelar, ésta no debe ser apreciada salvo que las bases adolecieran de alguna de las causas de nulidad del art. 62 LRJAP"147, no en vano "la nulidad de la convocatoria conllevaría la de todas las actuaciones realizadas a partir de la misma, lo cual podría plantear a poste riori cuantiosos problemas de difícil solución a los concursantes"148.

Ahora bien, aun cuando la doctrina jurisdiccional viene siendo prácticamente unánime al denegar la suspensión del acto impugnado cuando de la selección de personal público se trata, entendiendo que ha de prevalecer el interés general en la prosecución de las pruebas establecidas sobre el particular de los recurrentes, máxime si el número de plazas convocadas y de instancias formalizadas es elevado ${ }^{149}$, lo cierto es que la ponderación de las circunstan-

145 PARADA VÁZQUEZ, R.: Derecho del empleo público. Ley 7/2007, de 12 de abril, del Estatuto Básico del Empleado Público, Madrid, 2007, pág. 147.

146 LORENZO DE MEMBIELA, J.B.: EI acceso y la provisión de puestos de trabajo en la Administración Pública, cit., pág. 263.

147 ATCo 326/ 1996, de 11 de noviembre.

148 MANZANA LAGUARDA, R.: Derechos y deberes del funcionario público, Valencia, 2006, pág. 63.

149 STS 24 abril 1998 (RJ 4565). 
cias particulares de cada situación podría llevar a la solución contraria150, no en vano la Administración promotora siempre podría dar cobertura a la prestación del servicio utilizando los mecanismos previstos en la legislación vigente para paliar necesidades coyunturales de mano de obra, singularmente a través del posible reclutamiento de personal interino ${ }^{151}$. Salvo en los supuestos en los cuales el ordenamiento jurídico ha despojado a los actos administrativos de la prerrogativa de la ejecutividad -según ocurre, por ejemplo, en el ámbito de las reclamaciones económico-administrativas, las sanciones tributarias 0 , en general, en los casos en los que la impugnación viene fundamentada en una causa de nulidad de pleno derecho-, la regla general sigue siendo la ejecutividad de los actos administrativos, pero es necesario sopesar, sobre la concreta realidad, si el interés público exige o no la ejecución, no en vano -y como con acierto se ha dicho- "la rigidez es enemiga de la tutela cautelar y la flexibilidad su mejor aliada"152.

Dos reglas cobran relieve fundamental:

1) Cuando se impugnan "normas reglamentarias" que regulan aspectos concretos de la organización funcionarial y se solicita su suspensión, los Tribunales vienen a denegar la medida cautelar solicitada bajo el argumento genérico de que "los intereses inherentes a la adopción de una disposición general deben suponer los intereses consiguientes en que la medida aprobada prevalezca sobre los propios del recurrente en paralizarla": ponderación inclinada, por consiguiente, a la aplicación inmediata de la norma ${ }^{153}$.

150 TORNOS MAS, J.: "La tutela cautelar en sectores específicos del Derecho Público: extranjería, materia tributaria, función pública", en AA.VV (CAMPOS SÁNCHEZ-BORDONA, M.) : M e didas cautelares en la jurisdicción contencioso-administrativa, cit., pág. 247.

151 LORENZO DE MEMBIELA, J.B.: El acceso y la provisión de puestos de trabajo en la Administración Pública, cit., pág. 264.

152 CHINCHILLA MARÍN, C.: "Los criterios de adopción de las medidas cautelares en la nueva Ley reguladora de la jurisdicción contencioso-administrativa", en AA.VV (CAMPOS SÁNCHEZ-BORDONA, M., Dir.): M edidas cautelares en la jurisdicción contencioso-administrativa, cit., pág. 55.

153 ATS 3 julio 1996 (RJ 5594), negando la suspensión del RD 674/ 1993, de 7 de mayo, de provisión de puestos de trabajo en el extranjero y ascensos para funcionarios de la carrera diplomática; o ATS 4 julio 1999 (RJ 5873) con igual consecuencia respecto al reglamento relativo a normas básicas de acceso y provisión de puestos de trabajo en el Cuerpo de Inspectores de Educación. 
2) Idéntica tesis, matizada según el supuesto en presencia, se sigue al impugnar actos generales no normativos en procesos de selección o provisión de puestos: debe prevalecer el interés general en la prosecución de lo iniciado sobre el particular del recurrente; añadiéndose, en ocasiones, la necesidad de desempeñar eficazmente la tarea a la cual estarán destinados los funcionarios o destacando el el evado número de plazas convocadas e instancias presentadas para así permitir visualizar la trascendencia derivada de un acuerdo suspensivo ${ }^{154}$.

Descendiendo de lo abstracto a lo concreto, cabe mostrar tres ejemplos significativos en los cuales el criterio reseñado actúa sin fisuras, al punto de permitir aludir "a una doctrina reiterada en supuestos similares que afecten a una pluralidad de funcionarios, en los cuales los intereses públicos y generales que representa la decisión impugnada prevalecen sobre los intereses particulares de uno de los solicitantes"155:

A.- Ante la impugnación del proceso de cobertura de plazas judiciales por el Cuarto Turno, dos sentencias vienen a avalar la improcedencia de la medida cautelar instada.

La primera contempla "que siendo indudables los perjuicios que podrían seguirse para la actora como consecuencia de que se hubiere estimado su recurso administrativo, sin embargo no cabe negar que el Consejo General del Poder Judicial realizó una adecuada ponderación de los intereses en juego, dando razonable prevalencia al gravamen que la suspensión supondría para los intereses públicos y generales, representados por la conveniencia de la regular marcha en el tiempo de las pruebas para cubrir las plazas convocadas; interés relevante tanto en el orden de la más pronta acreditación de quienes pudieran acceder a la Escuela Judicial como en el de no perturbar la situación de los restantes interesados en la realización de las pruebas" ${ }^{\prime 156}$.

La segunda insiste y precisa las anteriores consideraciones, pues: a) "La ponderación de los intereses en conflicto hace prevalecer el interés general, que resultaría seriamente dañado con la suspensión del acto recurrido, atendiendo al fin esencial de proveer las vacantes de la carrera judicial, se verían afectadas las legítimas aspiraciones de quienes estarían privados de la defensa

154 SSTS 24 abril 1998 (RJ 4565) o 31 marzo 1999 (RJ 4415).

155 STSJ Extremadura 23 enero 2006 (JUR 63553).

156 STS 24 abril 1998 (RJ 4565). 
de sus intereses... b) [Es necesario] mantener el acto recurrido, y cumplimiento de los plazos previstos, máxime cuando no se acreditan perjuicios de muy elevada consideración, al pretenderse paralizar un proceso selectivo que atiende a la necesidad de proveer cuanto antes las plazas de referencia"157.

B.- De trasladar la perspectiva de la Justicia a la Educación, y ante un concurso de traslados impugnado en la Comunidad Autónoma de Extremadura, la doctrina se mantiene, al "afectar a un número importante de funcionarios (en el caso 254 docentes no universitarios) ..., lo que necesariamente incide tanto en los intereses de todos esos docentes como en el funcionamiento del servicio, ocasionando, de acceder a la suspensión, un perjuicio en la actividad pública ante las plazas que no serían ocupadas y los cambios que necesariamente se producirían en las vacantes"158.

C.- De acudir, en fin, a la Salud, ha sido declarado que "existe un indudable interés general en la efectividad de las disposiciones reglamentarias organizatorias, máxime cuando, en el ámbito objeto de este proceso, que es el de sanidad, es notorio el déficit de especialistas médicos"159.

Pero quizá los pronunciamientos más representativos al respecto vengan dados por aquellos dos relacionados con un concurso de traslados en el ámbito de las Instituciones Sanitarias del INSALU D, convocado por Resolución de su Dirección General de Recursos H umanos con fecha 25 de junio de 1998. El Tribunal Supremo, ante las distintas peticiones de suspensión del acto administrativo general (convocatoria de hasta un máximo de 4.200 plazas de personal facultativo especializado), ha señalado que acceder a tales solicitudes "Ilevaría consigo un evidente perjuicio al interés general, representado por la necesidad de proveer a la cobertura de las indicadas plazas conforme a la normativa y a las reglas dictadas para la resolución del concurso, destacando la Presidencia Ejecutiva del INSALUD que es necesario resolver el problema que afecta a todo el personal estatutario del INSALUD consistente en la falta de convocatoria de concursos de traslado durante los últimos nueve años, razón que debemos estimar como justificativa del grave perjuicio al interés general que produciría paralizar el desarrollo del concurso de traslados convocado

157 STS 12 septiembre 2000 (RJ 282/ 2001).

158 STSJ Extremadura 23 enero 2006 (JUR 63553).

${ }^{159}$ ATS 8 marzo 2001 (RJ 28428). 
respecto a un importante número de plazas de Facultativos Especialistas de Área... Los perjuicios que se producirían de prosperar el recurso interpuesto se limitarían a la privación de la plaza o plazas que no le hayan sido adjudicadas en el concurso de traslados como consecuencia del baremo de méritos impugnado y a las que hubiese concursado".

Se añaden, a mayor abundamiento, otros dos argumentos al daño derivado para la sociedad del retraso en la cobertura de las plazas convocadas: 1) "M edia grave perjuicio para intereses de los terceros que resultarían afectados por la suspensión postulada". 2) "La nulidad de pleno derecho de la Resolución impugnada o la vulneración de los derechos reconocidos por los artículos 9.2, 14, 23, 35 y 103 CE [debemos advertir que únicamente los derechos fundamentales establecidos en los artículos 14 y 23 CE pueden obtener protección por la vía del procedimiento regulado en la Ley 68/ 1978, ex disposición transitoria 2ªํㅡㄴ Ley $2 / 1979$, de 3 de octubre, Orgánica del Tribunal Constitucional] constituyen alegaciones del recurrente sobre las que habrá de resolverse en la sentencia que ponga fin al proceso, pero que no resultan ab in itio de una manifiesta evidencia o se fundan en resoluciones jurisprudenciales de casos idénticos que permitan decidir la suspensión de la ejecución del acuerdo impugnado con base en la doctrina de la apariencia de buen derecho del recurrente"160.

O bsérvese que ésta es la única referencia al fumus boni iuris tras la polémica supra expuesta: la apariencia de buen derecho en la petición del recurrente como causa determinante de la suspensión en la ejecución de actos administrativos sólo venía a ser admisible bajo condicionantes muy concretos "en los que resultaba ab initio de una manifiesta evidencia la apariencia de lesión a la legalidad cometida por la Administración o constaban sólidos antecedentes jurisprudenciales en los que, para casos iguales, se habían dictado sentencias estimatorias de los respectivos recursos"161.

En fin, habiendo centrado el discurso en la necesidad de sopesar los intereses en presencia, relativizando a sus estrictos márgenes el fumus bon is iuris, también los Tribunales abordan el periculum in mora, para negar que en estos casos la no suspensión produzca daños de imposible o difícil reparación; afirmando, por el contrario, que "tampoco existe una pérdida de la finalidad le-

${ }^{160}$ AATS 19 enero y 15 marzo 1999 (RJ 1494 y 2797).

${ }^{161}$ AATS 19 febrero, 8 marzo y 19 febrero 2001 (RJ 2845, 2848 y JUR 125589). 
gítima del recurso, pues no excluiría la posibilidad de ser convocada la parte recurrente, de producirse un fallo, en cuanto al fondo, estimatorio de la pretensión"162. Más claro aún: "los perjuicios para el recurrente son reparables, mediante la oportuna adjudicación de la plaza 0 , en última instancia, mediante indemnización"163.

\subsection{Revisión de los actos de reclutamiento y discrecionalidad técnica}

Cuestión distinta, pero directamente relacionada con la anterior, deriva de un posible recurso frente a las decisiones de los órganos de selección (vinculantes -como es lógico- para la Administración), en el cual se pide la paralización posterior del procedimiento administrativo, intentando evitar la toma de posesión de los candidatos propuestos para ocupar las plazas en cuestión.

Son muy variados los reproches que pueden hacerse a los actos a través de los cuales terminan los procesos selectivos: deficiencias orgánicas como es la irregular composición de los tribunales y, sobre todo, infracciones procedimentales o de fondo por haberse apartado la resolución de los criterios de capacidad y méritos implícitos en el procedimiento o consignados en la convocatoria o de los parámetros establecidos por las comisiones juzgadoras ${ }^{164}$. La reversibilidad o no de la decisión de los órganos de selección y bajo qué términos encuentra su nudo gordiano en el solo hecho de considerar cómo dentro de los márgenes fijados por las normas de obligado cumplimiento (incluyendo las bases de la convocatoria y los baremos de méritos), y sólo dentro de ellos, los órganos de selección gozan de discrecionalidad técnica para apreciar y comparar la capacidad de los diferentes candidatos ${ }^{165}$. De rancia raigambre en la doctrina, a partir de tal criterio los Tribunales no pueden sustituir con su parecer el de la autoridad técnica designada al efecto ${ }^{166}$ ( $n$ i siquiera cuan-

162 STS 12 septiembre 2000 (RJ 282/ 2001).

163 SSTS 19 enero y 15 marzo 1999 (RJ 1494 y 2973).

164 PARADA VÁZQUEZ, R.: Derecho del empleo público. Ley 7/2007, de 12 de abril, del Estatuto Básico del Empleado Público, cit., pág. 147.

165 SÁNCHEZ MORÓN, M.: Derecho de la Función Pública, cit., pág. 149.

166 Con origen en la STS 26 abril 1926, y un amplio y sostenido desarrollo que puede ser observado en el riguroso y documentado elenco de sentencias recogidas por TARDío PATO, J.A.: Control jurisdiccional de con cursos de méritos, oposiciones y exámenes académicos, Madrid, 1986, págs. 58-80. 
do medie prueba pericial en contrario ${ }^{167}$ ), pues tal excedería ampliamente el ámbito de la facultad judicial revisora ${ }^{168}$, los colapsaría ${ }^{169}$, atentaría contra verdaderos derechos subjetivos de los elegidos ${ }^{170}$ y significaría cambiar la opinión de especialistas por la de quienes carecen de aquella capacidad específica ${ }^{171} \mathrm{y}$, muchas veces, del conocimiento preciso de todos los datos para decidir ${ }^{172}$.

Según ha reconocido el propio Tribunal Supremo, "esa discrecionalidad técnica reduce las posibilidades del control de la actividad evaluadora, prácticamente constituidas por estos dos supuestos básicos: el de la inobservancia de los elementos reglados -cuando existan-, y el del error ostensible o manifiesto; $y$, consiguientemente, deja fuera de ese limitado control factible a aquellas pretensiones de los interesados que sólo postulen una evaluación alternativa a la del órgano calificador, pero moviéndose también dentro de ese aceptado espacio de libre apreciación, y no estén sustentadas con un posible error manifiesto... Ello explica la razón por la cual las normas reguladoras de la actuación de esos tribunales o comisiones sólo les exijan formalizar sus dictámenes o calificaciones mediante la expresión de la puntuación a partir de la cual se exteriorice su juicio técnico, y que tal dato numérico sea bastante para poder ser considerada formal mente correcta dicha actuación de evaluación técnica... Y cuando no exijan sino dicha puntuación, el calificador cumplirá con limitarse a exteriorizarla, y no podrá reprochársele, desde un punto de vista formal, el hecho de no acompañarla de una explicación o motivación complementaria"173.

167 STS 8 julio 1984 (Ar. 3641).

168 Por todas, ya las SST S 2 mayo 1972 (Ar. 2167) y 27 octubre 1973 (Ar. 4282). Por su contundencia, SSTS 12 febrero 1990 (Ar. 2281) o recogiendo abundantes precedentes, 1 marzo 1994 (Ar. 1627).

169 STS 28 marzo 1970 (Ar. 1801).

170 STS 30 octubre 1974 (Ar. 4175).

171 SSTS 28 abril 1976 (Ar. 1784), 18 julio 1988 (Ar. 5639) o 16 marzo y 28 septiembre 1989 (Ar. 2102 y 6374).

172 STS 17 diciembre 1986 (Ar. 7471). Un extenso comentario en PIÑAR MAÑAS, J.L.: “EI pleno control jurisdiccional de los concursos y oposiciones", Documentación Administrativa, núm. 220, 1989, págs. 139-141.

173 STS 14 julio 2000 (Ar. 7714). 
En breve, no es posible revisar el "núcleo material de la discrecionalidad"174 (en tal sentido "irreversible"175), aun cuando sí "sus aledaños"176, a saber: en aquellos supuestos reseñados "en los cuales sea evidente el error padecido"177, al punto de hacer "inaceptable la resolución con arreglo a los criterios de la sana crítica" por mor de la presencia de coacción, dolo, infracción normativa o de las bases de la convocatoria y, por supuesto, sí genera indefensión, es claramente arbitraria o muestra (y son el principal problema) patentes desviaciones de poder ${ }^{178}$.

Cuando cierto sector de la doctrina pretende hacer frente a la exclusividad de las comisiones para valorar los méritos y la capacidad de los candidatos, conoce perfectamente cuál es el objetivo a atacar: Ia tantas veces mencionada "discrecionalidad técnica"179. En su discurso contrapone ambos términos: "cuando hay discrecionalidad no puede hablarse de técnica, y cuando hay técnica no puede hablarse nunca de discrecionalidad... Lo técnico no se vaIora, se puede comprobar. Lo discrecional no se comprueba, se valora"180. Y, avanzando un paso más, sienta cómo, a partir de la exclusión del control jurisdiccional sobre el fondo, "se tendería no a la desaparición o reducción del

174 Por sólo rememorar la doctrina jurisdiccional desde el fundamental pronunciamiento dictado en interés de Ley y contenido en la STS 17 noviembre 1986 (Ar. 6149), entre muchísimas (además de la fundamental ST Co 215/ 1991, de 14 de noviembre), SSTS 3 febrero 1987 (Ar. 651), 19 julio 1988 (Ar. 5663), 8 noviembre 1989 (Ar. 7828), 18 enero 1990 (Ar. 81), 13 marzo 1991 (Ar. 2280), 20 y 25 octubre 1992 (Ar. 8485 y 8490), 25 febrero y 8 julio 1994 (Ar. 1301 y 6013), 28 mayo y 19 julio 1996 (Ar. 4654 y 5734), 11 octubre 1997 (Ar. 7789) ó 2 marzo y 27 octubre 1998 (Ar. 2723 y 7663 ).

175 SSTS 22 noviembre 1983 (Ar. 5427) o 27 junio 1986 (Ar. 4900).

176 SSTS 5 junio y 15 diciembre 1995 (Ar. 4870 y 9621) y 15 julio 1996 (Ar. 5704).

177 STSJ Canarias/ Sta. Cruz de Tenerife 29 julio 1998 (Ar. 2859). Sobre todo si se trata de errores aritméticos o matemáticos (STSJ Extremadura 29 junio 1998 -Ar. 2417-) y de mera traducción (STSJ 8 marzo 1998 -Ar. 679-).

178 SSTS 13 marzo y 30 abril 1991 (Ar. 2279), 20 octubre y 11 noviembre y 9 diciembre 1992 (Ar. 8485 y 9118 y 10147) o 30 abril 1993 (Ar. 2876).

179 FERNÁNDEZ DOMÍNGUEZ, J.J.: Acceso y movilidad de los funcionarios públicos (sobre la laboralización dealgunos núcleos duros de la función pública, Santiago de Compostela, 2003, págs. 218 y ss. 558.

180 GARCÍA-TREVIJANO FOS, J.A.: Tratado de Derecho Administrativo, T. I, Madrid, 1968, pág. 
ámbito de zonas infiscalizables consagradas por la L ey de Jurisdicción de lo Contencioso..., sino que se habría llegado paradójicamente a una ampliación de las mismas..., y a una segunda versión, corregida y aumentada, de la exclusión legal"181; o, ni siquiera a tan arbitrario resultado, sino a una "exclusión formal, sin encaje legal, realizada exclusivamente por la jurisprudencia y la doctrina"182.

El paso fundamental había sido dado y el camino quedaba abierto para, acto seguido, repudiar la invocación del carácter revisor de la jurisdicción de lo contencioso en la materia (diferenciando la discrecionalidad técnica de la administrativa) ${ }^{183}$, criticar el argumento específico de la insustituibilidad de los juicios y de los juzgadores integrados en los órganos calificadores, defender la competencia técnica especializada de los Tribunales a partir de la admisión de la prueba pericial ${ }^{184}$, atacar el fundamento de las "valoraciones conjuntas o globales para negar la posibilidad de efectuar un análisis individualizado de cada una de ellas ${ }^{185}$, superar el criterio conforme al cual la propuesta de la comisión crea un derecho subjetivo a favor del propuesto y, al final, negar la existencia de un margen de libre apreciación no revisable en vía jurisdiccional ${ }^{186}$, a riesgo de llevar directamente al abuso de derecho ${ }^{187}$ en una

181 COCA VITA, E.: “Legalidad constitucional, exclusión de control judicial y discrecionalidad técnica", Revista de Administración Pública, núms. 100-102, 1983, págs. 1073-1074y, también, "La discrecionalidad técnica bajo el control último de los Tribunales", Revista de Administración Pública, núm. 108, 1985, págs. 205 y ss.

182 TARDíO PATO, J.A.: Control jurisdiccional de concursos de méritos, oposiciones y exámenes acadé micos, cit., pág. 168.

183 PIÑAR MAÑAS, J.L.: “El pleno control jurisdiccional de los concursos y oposiciones”, Documentación Administrativa, núm. 220, 1989, pág. 148.

184 TARDíO PATO, J.A.: Control jurisdiccional de concursos, oposiciones y exámenes académicos, cit., págs. 172-179.

185 GALLEgo ANABITARTE, A.: "Prólogo", a la obra de MOZO SEOANE, A.: La discrecionalidad de la Administración Pública en España. Análisis jurisprudencial, legislativo y doctrinal (1894-1983), Madrid, 1985, pág. 34.

186 TARDíO PATO, J.A.: Control jurisdiccional de concursos, oposiciones y exámenes académicos, cit., págs. 186-189.

187 SANTAMARÍA PAST OR, J.A.: "Renovación dogmática en torno a la desviación de poder como instrumento de control", Revista Española de Derecho Administrativo, núm. 2, 1974, pág. 3030 SORIANO GARCÍA, J.E.: "H acia el control de la desviación de poder por omisión", Revista Española de Derecho Administrativo, núms. 40-41, 1983, pág. 178. Por todos, valgan las reflexiones de CHINCHILLA MARÍN, C.: La desviación de poder, Madrid, 1989, especialmente págs. 42 y ss. 
materia en la cual no puede existir discrecionalidad por no concurrir varias opciones justas, sino una sola: la derivada del mérito y capacidad ${ }^{188}$.

El Tribunal Constitucional tercia en la polémica doctrinal y, con apoyo en la jurisprudencia mayoritaria -también en Derecho Comunitario ${ }^{189}$-, proporciona un impulso definitivo a la tesis clásica ${ }^{190}$, al confirmar -en fundamental pronunciamiento ${ }^{191}$ _ todos y cada uno de sus asertos ( reflejando "el estado de la cuestión acerca del control de la discrecionalidad en este punto al incorpo-

188 PIÑAR MAÑAS, J.L.: "EI pleno control jurisdiccional de los concursos y oposiciones", cit., págs. 152 y ss.

189 Baste remitir a los supuestos, ya clásicos, decididos en Ias SSTJCE 112, 144 y 145/ 1973, de 9 octubre de 1974, asuntos acumulados Campogrande; 7/ 1977, de 16 de marzo de 1978, asunto WüIlerstorff; 316/ 1982 y 40/ 1983, de 9 de febrero de 1984, asunto Khow o 162/ 1984, de 28 de noviembre de 1985, asunto Androniki Vlachou.

190 Entre otros, NIETO GARCÍA, A.: “Reducción jurisdiccional de la discrecionalidad en materia disciplinaria", Revista de Administración Pública, núm. 44, 1964, págs. 147 y ss. y Estudios históricos sobre la Administración y Derecho Administrativo, Madrid, 1986, especialmente págs. 263 y sS.; MARTíNEZ MORALES, J.L.: "Las pruebas de idoneidad. Un avance jurisprudencial en el control de la discrecionalidad técnica", Revista Española de Derecho Administrativo, núm. 47, 1985, págs. 413 y ss.; GONZÁLEZ BERENGUER, J.L.: "M ateria contenciosa y fiscalización de la discrecionalidad", Revista de Administración Pública, núm. 37, 1962, pág. 166; GARCÍA DE ENTERRÍA, E.: "La lucha contra las inmunidades del poder en el Derecho Administrativo", Revista de Administración Pública, núm. 38, 1962, págs. 175 y sS. o SÁNCHEZ BLANCO, A.: "La discrecionalidad técnica de los tribunales de oposiciones y concursos", Revista de Administración Pública, núm. 30, 1981, págs. 563 y ss.

Sobre la nueva línea abierta por el Tribunal Constitucional, procede la remisión a las obras de GARCÍA DE ENTERRÍA, E.: "Los ciudadanos y la Administración", en AA.VV.: H acia una justicia administrativa, Madrid, 1989, págs. 97 y ss.; MARTÍN RETORTILLO BAQUER, L.: "Del control de la discrecionalidad administrativa al control de la discrecionalidad judicial", Revista de Administración Pública, núms. 100-102, 1983, pág. 1098; PAREJO ALFONSO, L.: Crisis y renovación del Derecho Público, Madrid, 1991, pág. 77 o Administrar y juzgar, dos funciones constitucionales distintas y comple mentarias, Madrid, 1993, especialmente págs. 42 y ss.; SÁNCHEZ MORÓN, M.: El control de las Administraciones Públicas y sus problemas, Madrid, 1991, págs. 120 y ss. y Discrecionalidad administrativa y control judicial, Madrid, 1994, págs. 53 y ss.; BELTRÁN DE FELIPE, M.: Discrecionalidad administrativa y Constitución, Madrid, 1995, págs. 15 y ss. o MUÑOZ MACHADO, S.: La reserva de jurisdicción, Madrid, 1989, pág. 108.

191 ST Co 39/ 1983, de 16 de mayo, posteriormente ratificada por SST Co 110 y 215/ 1991, de 20 de mayo y 14 diciembre; 97 y 353/ 1993, de 22 de marzo y 29 noviembre o 34/ 1995, de 6 febrero. En la jurisprudencia, SSTS 25 octubre 1992 (Ar. 8490) y 8 julio 1994 (Ar. 5677). Exhaustivo el análisis de PEÑARRU BIA IZA, J.Mạ: "La moderna jurisprudencia sobre discrecionalidad técnica", Re vista de Administración Pública, núm. 136, 1995, págs. 327 y ss. 
rar a su prosa sistemas de conceptos habituales ya en la doctrina y en la jurisprudencia de lo contencioso"192), a saber ${ }^{193 .}$

1.- El juicio no recae sobre una cuestión de legalidad, ni siquiera sobre una jurídica, sino meramente técnica (incluyendo, por supuesto, la posibilidad de anular preguntas inadecuadas al programa de las pruebas a reali$z^{194}{ }^{194}$, y, por tanto, escapa "por su propia naturaleza" (actividad de mera ejecución, frente a potestad normativa ${ }^{195}$ ) al control jurisdiccional ${ }^{196}$.

2.- El criterio adoptado sobre la idoneidad de los aspirantes constituye un caso de "valoración conjunta" de las diversas circunstancias concurrentes en la aptitud sopesada.

3.- A resultas de los dos postulados anteriores, la apreciación sólo puede ser realizada por órganos especializados al efecto, y no por Tribunales de Justicia: insustituibilidad del juicio y del juzgador vinculado al criterio de competencia técnica especializada.

4.- La deferencia apuntada hacia la discrecionalidad técnica de los tribunales y comisiones de concursos y oposiciones encuentra fundamento en una presunción iuris tantum de certeza y razonabilidad en su actuación, apoyada en su especialización e imparcialidad a la hora de realizar las calificaciones. Sólo en caso de demostrar desviación de poder o errores palmarios y groseros cabrá anular sus decisiones en cuanto tienen de discrecionales ${ }^{197}$.

192 MARTÍN-RETORTILLO BAQUER, L.: "Del control de la discrecionalidad administrativa al control de la discrecionalidad judicial", cit., pág. 1048.

193 Siguiendo el certero resumen de TARDíO PATO, J.A.: Control jurisdiccional de concursos, oposiciones y exámenes académicos, cit., pág. 162.

194 ALONSO MAS, Mạ..: "La fiscalización jurisdiccional de las pruebas tipo test para el acceso a la función pública", Revista de Administración Pública, núm. 144, 1997, págs. 171-217.

195 Según muestra -entre varias- la magnífica STS 6 noviembre 1984 (Ar. 5758) .

196 Sirva, por todas, la STS 3 noviembre 1980 (Ar. 4252).

197 ST Co 34/ 1995, de 6 de febrero. 
A partir de tal momento queda clara la regla general de exención del núcleo de la decisión ${ }^{198}$; persisten, empero, límites conquistados en el pasado a partir de la distinción entre discrecionalidad "selectiva" y "técnica"199 ( "control de legalidad y control técnico"200): queda limitada a los casos de oposición o concurso-oposición en la fase de oposición, pero no alcanza a los concursos de méritos ${ }^{201}$, y "no tiene un valor tan absoluto como para excluir cualquier tipo de matización..., un control de hechos determinantes"202; exige, además, diferenciar (siempre y cuando sea factible y admisible) entre sistemas que incluyen criterios y sistemas de calificación (operación reglada a partir de las bases de la convocatoria ${ }^{203}$ ) de cuantos otros no lo hacen (en suma, amplio margen) ${ }^{204 .}$

En consecuencia, cabe extraer un doble criterio 205 :

A) Regla general: prevalencia absoluta de la discrecionalidad técnica del tribunal o de la comisión frente a otros criterios expertos aportados por los

198 STS 27 abril 1990 (Ar. 3568), remitiendo a la STS 8 noviembre 1989 (Ar. 7828). La línea luego es continuada por las SSTS 21 enero 1991 (Ar. 1321), 8 marzo, 2 y 22 abril 1993 (Ar. 2108, 2757 y 2804). Con carácter reciente, SSTS 1 y 29 octubre y 27 noviembre 2007 (TOL 1177748, 1220928 y 1210148).

199 Excelentes muestras al respecto las ofrecidas en la STS 23 mayo 1992 (Ar. 3663); más actuales, SSTS 18 junio, 16 y 20 julio y 26 septiembre 2007 (TOL 1107102, 1124349, 1124362 y 1156869).

200 ST S 14 diciembre 1988 (Ar. 9703); asimismo, SSTS 30 marzo, 18 abril y 10 y 18 mayo 2007 (TOL 1059144, 1076335, 1107102 y 1081901).

201 CASTILLO BLANCO, F.A.: Acceso a la función pública local (políticas selectivas y control jurisdiccional), Granada, 1993, págs. 122 y ss.

202 ST S 17 marzo 1992 (Ar. 1585). Asimismo, SSTS 19 junio 2006 y 6 marzo 2007 (TOL 967607 y 1060359),

203 SST S 28 noviembre 1984 (Ar. 5983), 21 junio 1985 (Ar. 4172), 19 mayo 1989 (Ar. 3796), 21 febrero 1992 (Ar. 1028) ó, más actual, STS 2 marzo 2007 (TOL 1060359).

204 TARDíO PATO, J.A.: Control jurisdiccional de concursos, oposiciones y exámenes académicos, cit., págs. 109-120.

205 Siguiendo a CASTILLO BLANCO, F.A.: Acceso a la función pública local, oposiciones y exámenes académicos, cit., pág. 131. 
concursantes, en tanto lo contrario supondría extender la facultad revisora de la jurisdicción, lo cual no es de recibo 206 .

B) Regla especial, admitiendo la revisibilidad cuando: a) la propia comisión o el tribunal se autoimponga normas y así autolimite sus facultades ${ }^{207}$; b) no cumpla los requisitos formales o de procedimiento establecidos en la convocatoria ${ }^{208}$, no motive suficientemente la resolución del concurso ${ }^{209}$, el interesado consiga acreditar la existencia de vicios en la formación de su pare$\operatorname{cer}^{210}$ ( para lo cual queda garantizado el derecho al acceso al expediente del resto de los aspirantes ${ }^{211}$ ) o su juicio aparezca viciado por desviación de poder o patente arbitrariedad 212 convenientemente acreditada por el impugnan$\mathrm{te}^{213}$. En resumen, cuando de la discrecionalidad se pasa a la arbitrariedad 214.

Las reflexiones anteriores sirven como pórtico para argumentar cómo esa discrecionalidad técnica no significa que los tribunales y comisiones, que resuelven las oposiciones y concursos, sean soberanos, como solía expresar la jurisprudencia tradicional para señalar la imposibilidad de controlar el fondo de

\footnotetext{
${ }^{206}$ Firme el bastión enarbolado por la clásica, y tantas veces citada, STS 21 diciembre 1961 (Ar. 4354). Más recientes, SSTS 16 octubre y 5 noviembre 2007 (TOL 1777788 y 1214216).

207 ST S 7 diciembre 1983 (Ar. 6264); también, SSTS 20 noviembre 2006 (TOL 1018620) y 10 octubre 2007 ( 1161249 ).
}

208 SSTCo 115/ 1996, de 25 junio y 96/ 1997, de 19 mayo o SSTS 18 noviembre 1986 (Ar. 4172), 21 junio 1987 (Ar. 903), 23 septiembre 1988 (Ar. 6817), 26 diciembre 1989 (Ar. 9479) o, entre muchas, 24 septiembre 2007 (TOL 1081875).

209 Por todas, STS 28 marzo 1970 (Ar. 1328).

210 SSTS 15 febrero 1990 (Ar. 4971) y 8 julio 1994 (Ar. 6478).

${ }^{211}$ STS 4 abril y 1 junio 2007 (TOL 1081875 y 1107051).

212 Sirva el magnífico ejemplo proporcionado por la STS 31 marzo 1966 (Ar. 1927). Entre las más recientes, por su contundencia, STS 7 julio 2006 (TOL 979686). Imprescindible la referencia a la obra de CHINCHILLA MARÍN, C.: La desviación de poder, cit., págs. 42 y ss., y bibliografía allí citada.

213 STS 7 julio 2007 (TOL 979686).

214 SSTS 19 febrero 1991 (Ar. 1329), 11 noviembre 1992 (Ar. 9118), 10 junio y 20 octubre 1993 (Ar. 45064 y 7640) o, por no seguir, 2 marzo 2007 (TOL 1060359). 
sus decisiones, pero sí que los juicios meramente técnicos que emitan sobre cada candidato no pueden ser revisados en vía de recurso, salvo demostración adecuada por quien impugna de la existencia de una desviación de poder 0 de una clara, manifiesta y evidente arbitrariedad o desigualdad de trato o un patente error ${ }^{215}$. Tal interpretación ha sido criticada por cierto sector de la doctrina, que considera esta autolimitación de los órganos judiciales como un atentado al principio de la garantía judicial efectiva, pues lo que de ordinario se discute en estos procesos ( y para evitar perjuicios irreparables se pide la suspensión cautelar) es justamente si están bien resueltos conforme a criterios técnicos. Sustraer estos aspectos del debate procesal es dejarlo sin sustancia. Nada impediría que los jueces controlaran la justeza con la cual se aplicaron los criterios técnicos practicando las oportunas pruebas periciales Ilamando al proceso a expertos de la misma o superior categoría y apoyando en sus juicios la revisión de las resoluciones de los órganos administrativos de evaluación. "Ni más ni menos que lo mismo que se hace en tantos procesos contencioso-administrativos en que se implican cuestiones técnicas y económicas muy complejas donde los jueces suplen su falta de preparación Ilamando al proceso a peritos de las más variadas especialidades"216.

\section{REFLEXIONES FINALES}

La exigencia de dotar continuidad y regularidad al quehacer de las Administraciones conlleva el reconocimiento del denominado "privilegio de autotutela", que entronca así con el principio de eficacia enunciado en el art. 103 CE y supone partir de una presunción iuris tantum de legalidad que determina su ejecutividad inmediata y ejecutoriedad ulterior.

El hecho de reconocer a los órganos judiciales la facultad de adoptar medidas cautelares que permitan asegurar el resultado del proceso siempre que sea necesario no supone, en modo alguno, una equiparación entre ejecutividad y suspensión; más bien al contrario, lleva a confirmar una dialéctica de décadas entre un privilegio general y la mera facultad de inutilizarlo exclusivamente ante determinados supuestos; a saber, que tras una ponderación suficientemente motivada de todos los intereses en presencia considere que la eje-

215 SÁNCHEZ MORÓ N, M.: Derecho de la Función Pública, cit., pág. 149.

216 PARADA VÁZQUEZ, R.: Derecho del empleo público. La Ley 7/2007, de 12 de abril, del Estatuto Básico del Empleado Público, cit., pág. 148. 
cución del acto puede hacer perder la finalidad al recurso o causar perturbación grave a los intereses generales o de terceros. La suspensión es, de este modo, una medida calificada por los Tribunales como "provisionalísima", exigiendo suma cautela a la hora de otorgarla 0 , si se prefiere, una interpretación estricta de sus requisitos.

Así, de atender a los criterios acumulativamente -no, por tanto, de forma alternativa o excluyente- exigidos para la concesión de la suspensión, procederá observar cómo el llamado a actuar como primer parámetro a sopesar para conceder o no la medida cautelar, el periculum in mora ( o necesidad de que el recurso contencioso no quede privado de su legítima finalidad y la sentencia que en su día se dicte acabe constituyendo una mera declaración solemne y formal de estimación), presenta dos vertientes: de un lado, la clásica, situada en el carácter irreparable del perjuicio causado; de otro, la de nuevo cuño, dada por advertir que, "de modo inmediato", pueda producirse una situación que haga ineficaz el proceso. Sopesando la primera de ellas, cabe comprobar cómo la no suspensión del acto administrativo impugnado en el marco de un proceso de selección de funcionarios constituye un claro ejemplo de resarcimiento sin mayores complicaciones, al caber la reparación del daño causado adscribiendo a los recurrentes a la plaza que resulte de la declaración judicial y/ o, en última instancia, reconociéndoles una indemnización adicional o alternativa. Parando mientes en la segunda de las facetas supra señaladas, procederá recordar las numerosas sentencias que deniegan la suspensión cuando es de esperar que en un período limitado de tiempo se decida sobre el fondo. Aquí es fácil corroborar lo dicho, con solo remitir a los plazos legales para resolver en alzada y el juego del silencio administrativo negativo en su defecto, abriendo en un mes la vía judicial.

La ponderación de los intereses concurrentes complementa o completa el periculum in mora, obligando a sopesar tanto el interés general y público como el particular o privado de las personas afectadas, considerando siempre las circunstancias particulares de cada situación. Este reenvío a lo singular, que aboca a un régimen marcadamente casuístico, habrá de actuar, no obstante, sobre una máxima que recuerdan constantemente los Tribunales: cuando las exigencias de ejecución que el interés público presentan son tenues, bastarán perjuicios de escasa entidad para provocar la suspensión; por el contrario, si lo son de gran intensidad, sólo daños de elevada consideración podrán llevar a su concesión. $\mathrm{H}$ abitualmente la aplicación del criterio enunciado lleva a una prevalencia del interés general; pero en los casos relativos al reclutamiento de funcionarios deviene palmario que debe hacerlo, atendiendo a la necesaria prestación con eficacia de los servicios públicos a favor de los ciudadanos que la Administración debe asumir en todo caso. 
La apariencia de buen derecho ( fumus boni iuris), o enjuiciamiento por el Juez o Tribunal de las probabilidades de que la sentencia pueda ser favorable a las pretensiones del actor, constituye una doctrina tan difundida como -según recuerda repetidamente la jurisprudencia- necesitada de prudente aplicación, pues muchas veces entraña un examen sobre el fondo del asunto que no es susceptible de ser tratado, por lo general, en una pieza de suspensión. De hecho, y como regla, no cabe su invocación cuando se trata de un acto que ha de ser por primera vez objeto de valoración o decisión, pues se vulneraría el derecho a un proceso con las garantías debidas de contradicción y prueba. No hace falta recordar siquiera que esto es precisamente cuanto acaece en los procesos de selección de funcionarios, a no ser que concurran las circunstancias habilitantes para su operatividad excepcional: por una parte, sólidos antecedentes sobre casos iguales en los cuales hubieran sido dictadas sentencias estimatorias de los respectivos recursos; por otra, nulidad patente, manifiesta y evidente a todas luces.

En fin, descartando con carácter general la concurrencia de los requisitos exigidos para acordar la suspensión del acto impugnado, y de considerar las pautas judiciales en los procesos de selección de funcionarios, procederá aludir a los tres siguientes supuestos, convertidos en doctrina legal por su reiteración:

En primer lugar, dentro de los márgenes fijados por las normas de obligado cumplimiento (incluyendo las bases de la convocatoria y los baremos de méritos), y sólo dentro de ellos, los órganos de selección gozan de discrecionalidad técnica para apreciar y comparar los méritos y la capacidad de los diferentes candidatos.

En segundo término, cuando se impugnan actos generales no normativos en sectores tales como la Justicia, Educación o Sanidad, viene a otorgarse prevalencia al interés general en la prosecución de lo iniciado sobre el interés particular del recurrente. Dos son los motivos principales: de un lado, la urgencia en proveer las vacantes para el normal funcionamiento del servicio público; de otro, el interés de cuantos han sido admitidos y aspiran legítimamente a ocupar en tiempo y forma tales plazas. A los anteriores se añaden, en ocasiones, otros dos: la necesidad de desempeñar eficazmente la tarea a la cual están destinados los funcionarios y el elevado número de puestos convocados e instancias presentadas, para así permitir visualizar la entidad del problema.

En tercer lugar, se destaca convenientemente que no existe periculum in mora alguno, pues nada impedirá la admisión de los excluidos o la corrección 
en el baremo cuando así lo considere oportuno una sentencia estimatoria del recurso. De este modo, los perjuicios son clara y fácilmente reparables a través de la adjudicación de la plaza, si fuere menester, o, en última instancia, mediante indemnización.

La doctrina jurisdiccional viene siendo, pues, prácticamente unánime al denegar la suspensión del acto impugnado cuando de procesos de selección de personal público se trata, entendiendo que ha de prevalecer el interés general en la prosecución de las pruebas establecidas sobre el interés particular de los recurrentes, máxime si el número de plazas convocadas y de instancias formalizado es elevado. 